بعض الملامح التسويقية للبلح فى محافظه الوادى الجديد

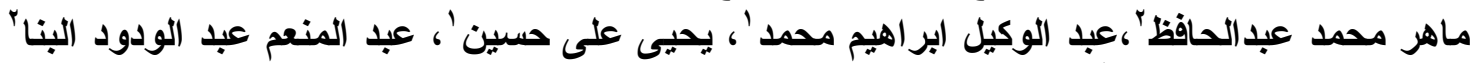

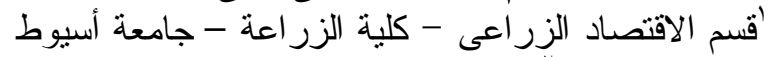
كركز البحوث الزر اعيه

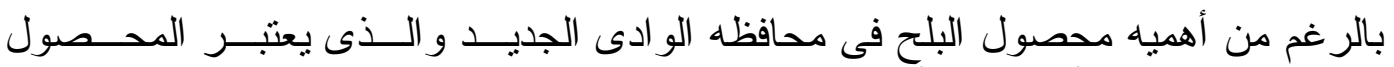

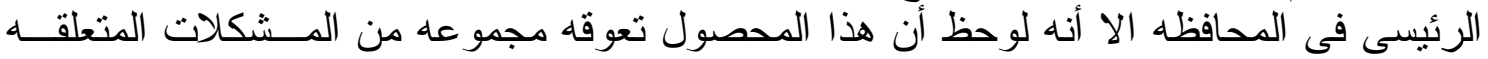

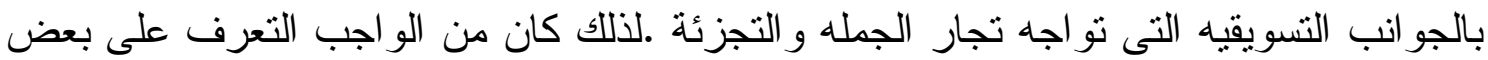
الملامح التسويقية لمحصول البلح فى محافظة الو ادى الجديد بالاضافة الى المشكلات التهات التى تعوق التى

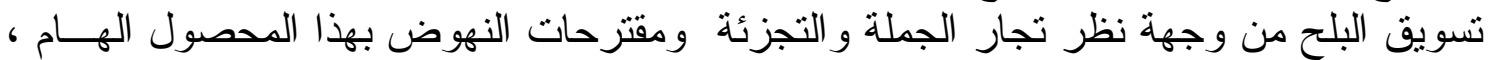

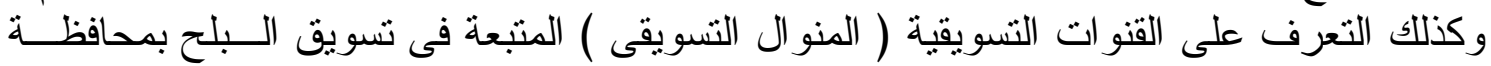
وقد أعتمدت الدر اسه فى تحقيق اهدافها على البيانات الاولية التى تم جمعها مــن خـــلال استمارتى استبيان احداها لتجار الجملة و الآخرى لتجار التجزئة ، وشملت العينة على أختيار

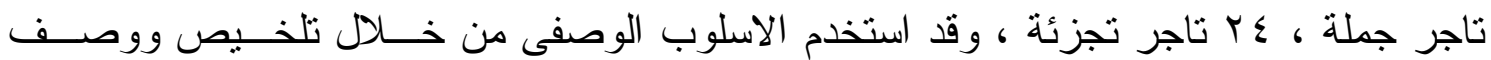

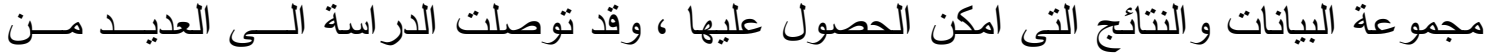

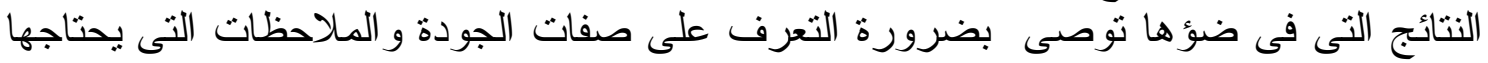

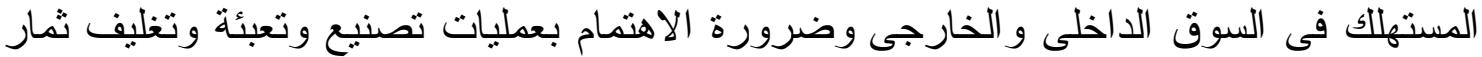

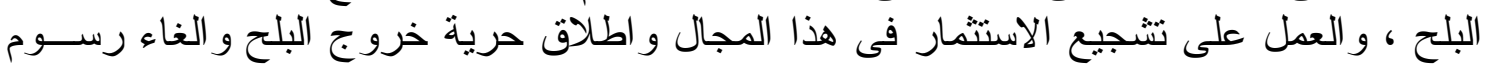

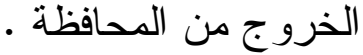

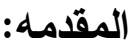

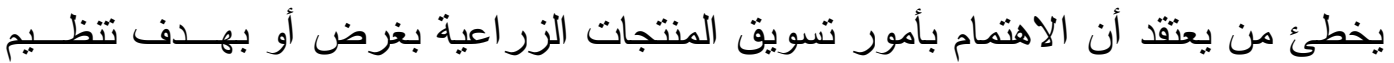

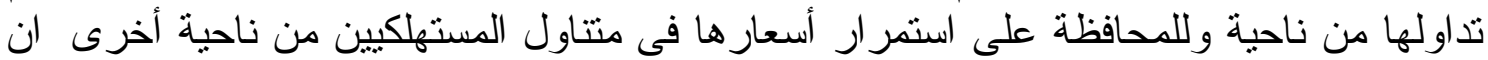

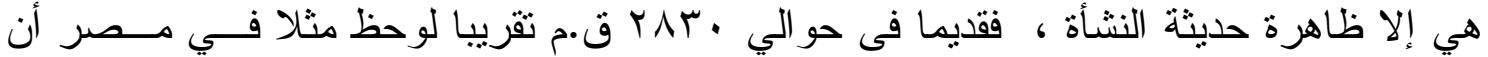

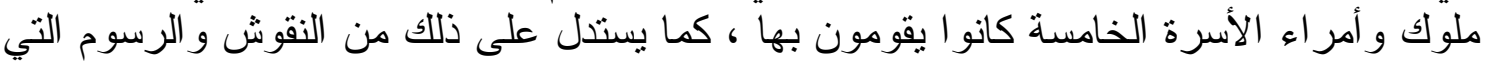
وجدت على مقابر هم ببعض المعلومات المرتبطة بتسويق حاصلاتهم ، كقيامهم بتخزين الكثيــر من المنتجات الزر اعية وذلك بهدف العمل على تتظيم استهلاكها بو اسطة السكان .

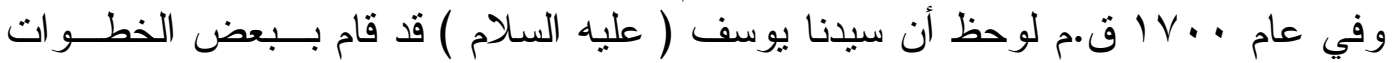

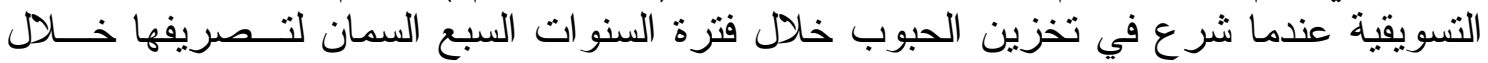
فترة السنو ات السبع العجاف ، وذللك بغية تحقيق ما كان ينشده من إحداث تو الن إن سليم بن الإنتاج

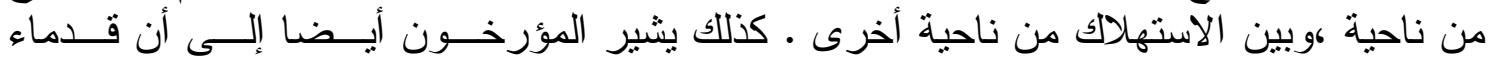

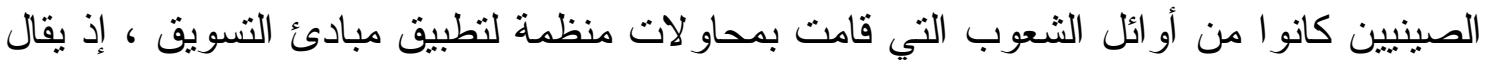

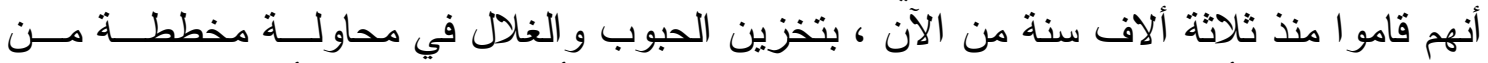

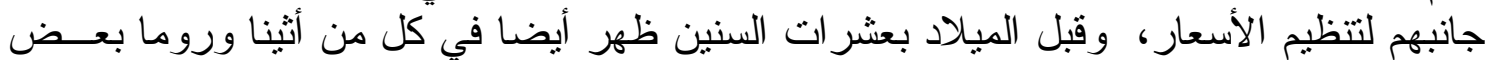

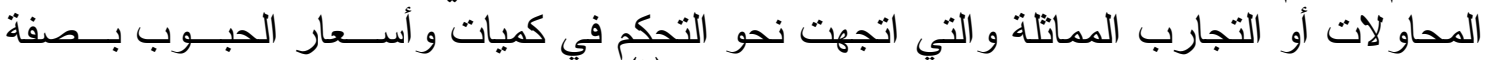

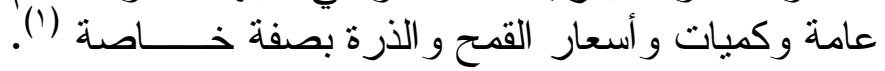

Received on: $8 / 3 / 2014$

Referees: Prof. Talaat H. Ismail
Accepted for publication on: 26/3/2014

Prof. Mohamed A. Mohamed 
وبمرور الزمن تطورت الأساليب التي تستخدمها الدول في تسويق حاصـــاتها الزر اعيـــة

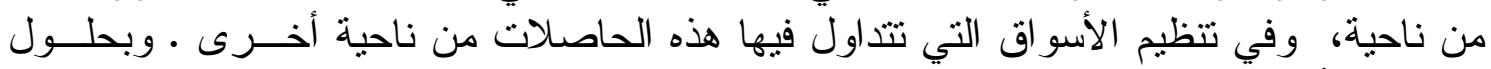

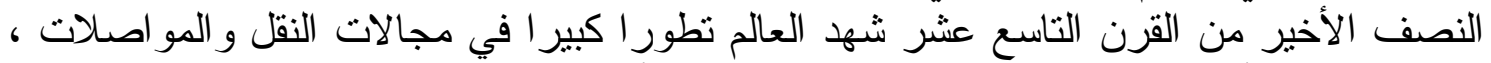

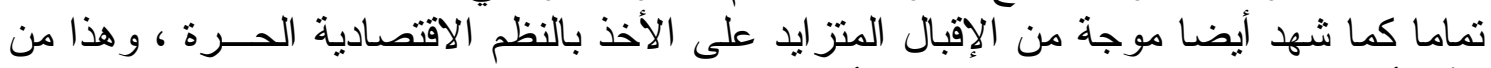

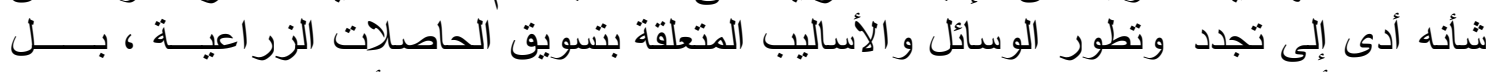

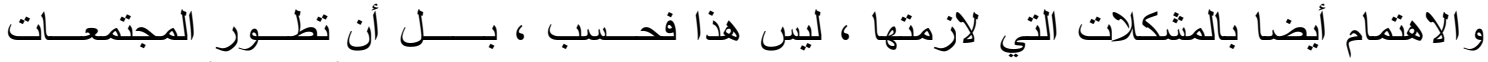

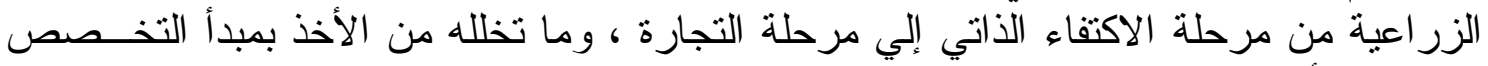

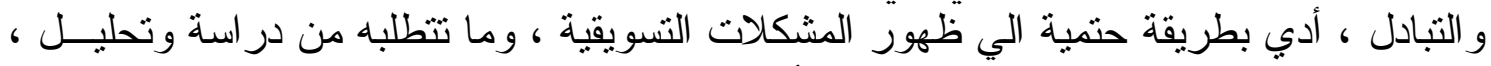

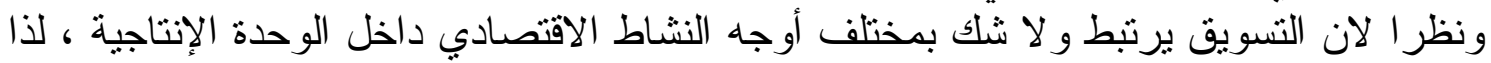

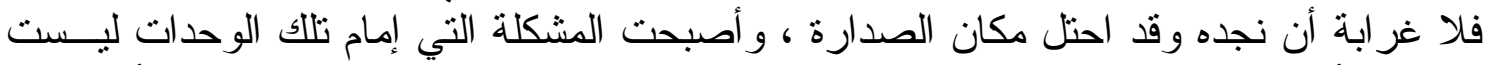

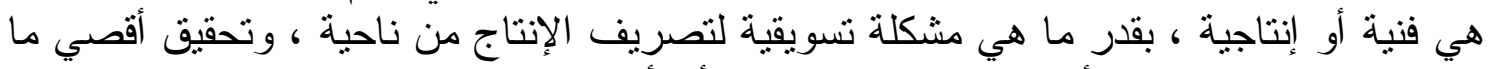

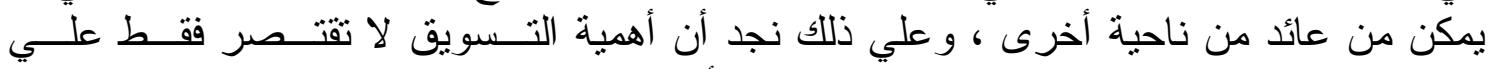

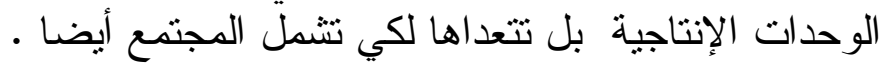
مشكلة البحث: التش

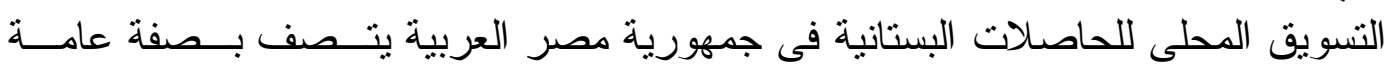

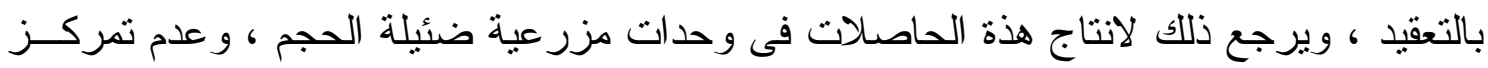

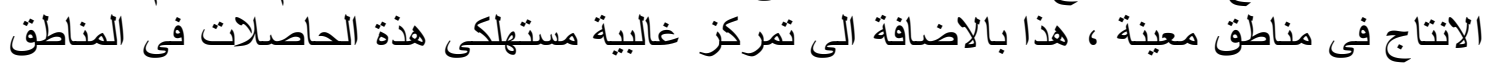

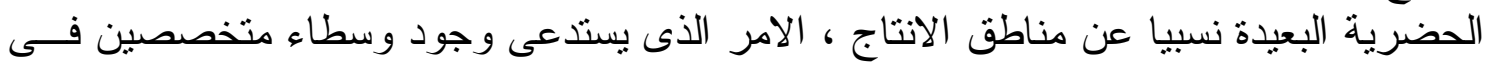

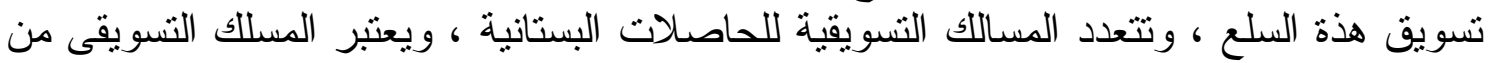

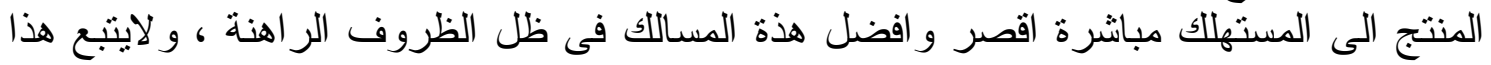
المسلك التسويقى سوى صغار المز ارعين ، كما انه من المشاهد انة ليس ذو الهئ الهمية كبيرة حاليا .

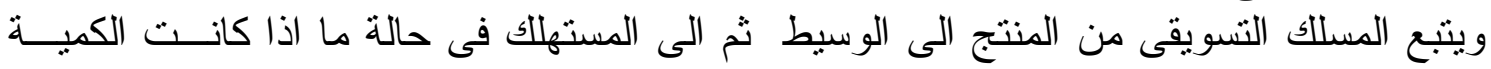

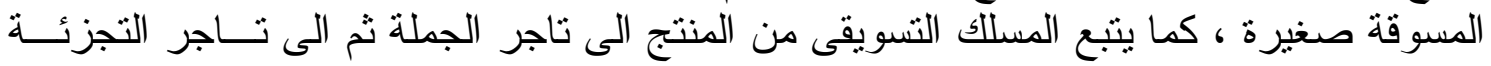

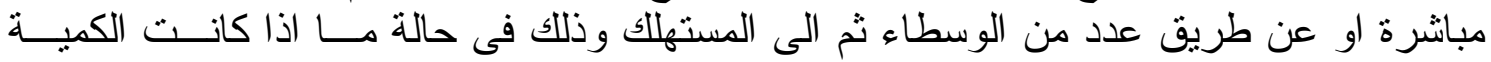

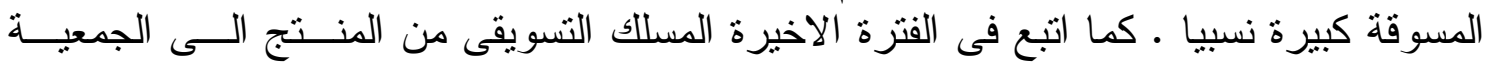

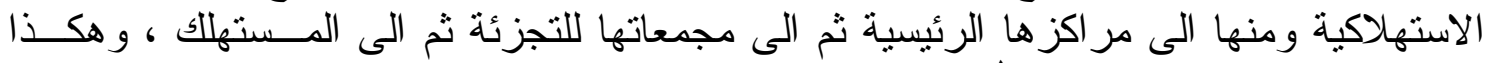

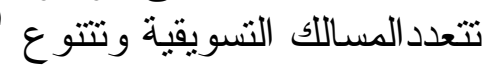

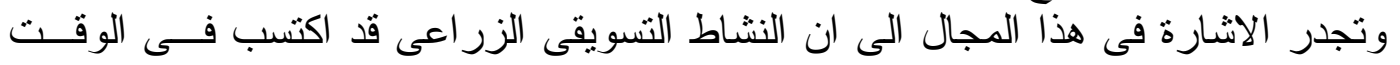

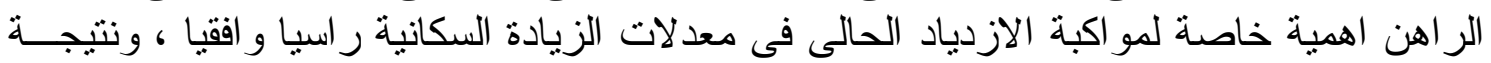

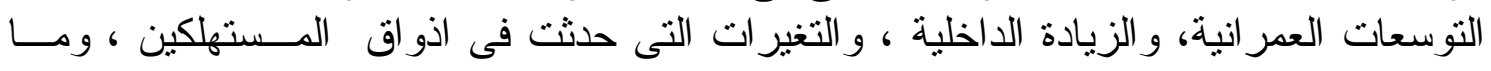

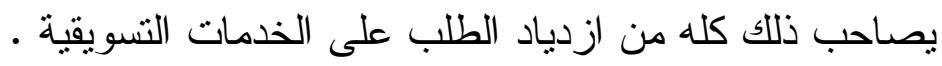

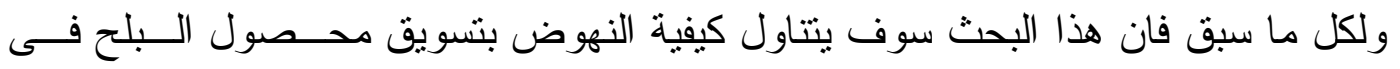

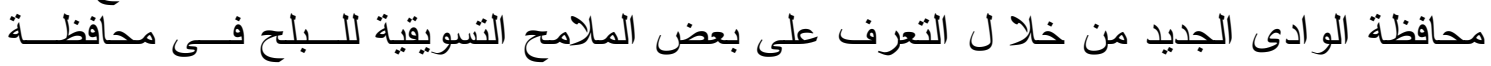

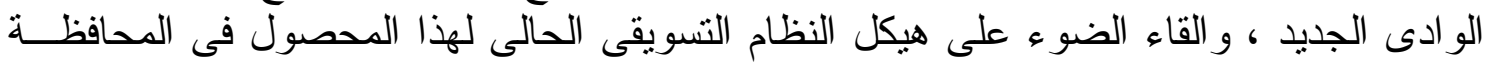

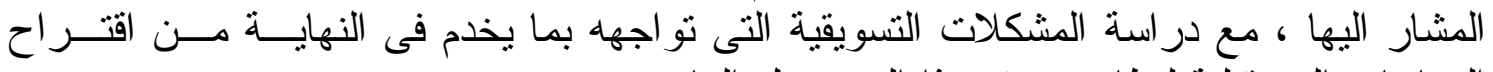

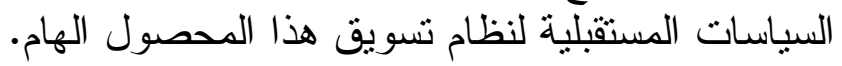
اللهدف من البحث:

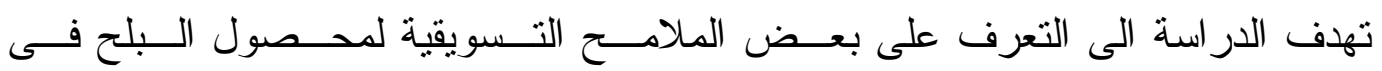

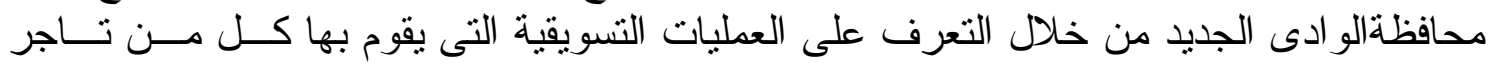

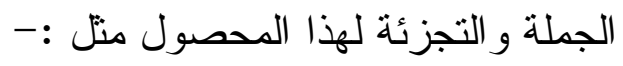




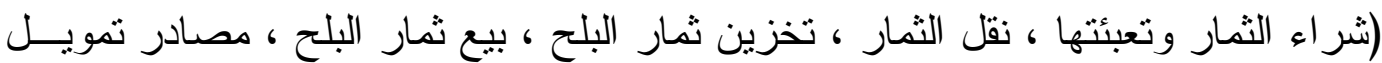

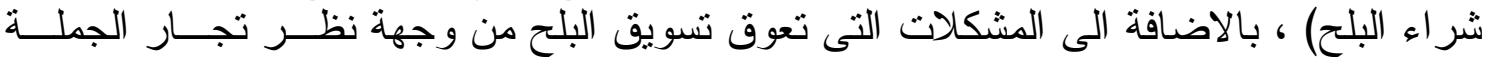

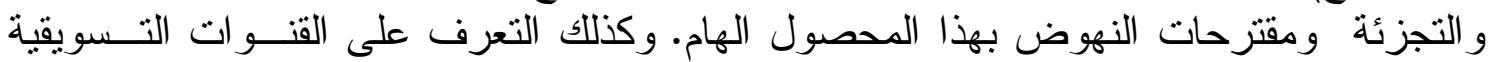
(المنو ال التسويقى) المتبعة فى تسويق البلح بمحافظة الو ادى الجديد.

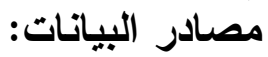

نظر اللاهية القصوى لنوع البيانات اللازمة لدراسة اية مشكلة او اى هدف ، فقد استلزم

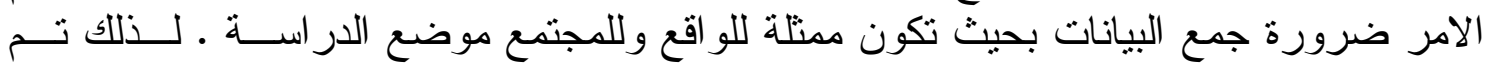

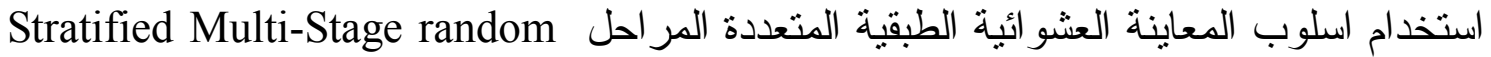

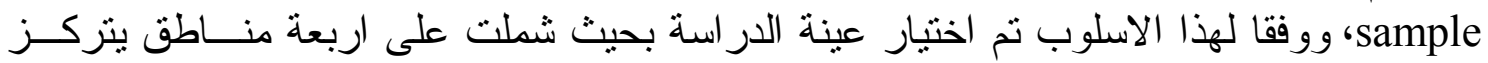

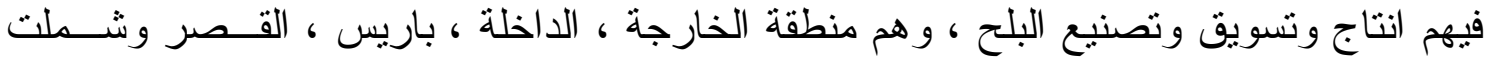

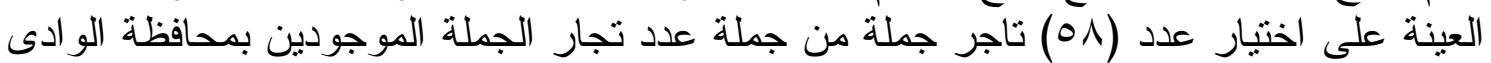

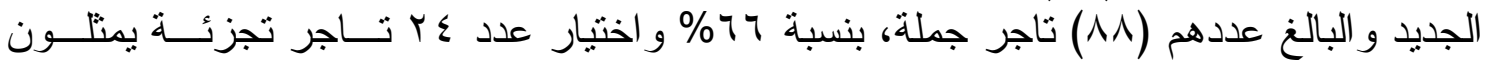

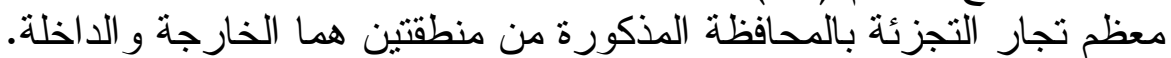

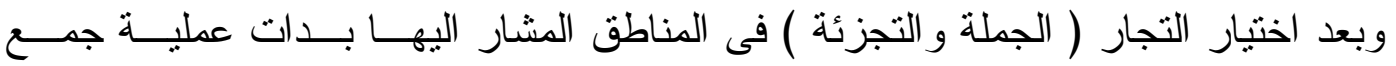

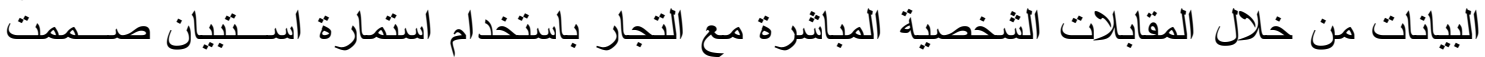
لتجار الجملة واخرى صممت لتجان لتجار التجزئة.

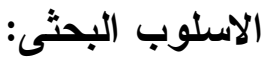

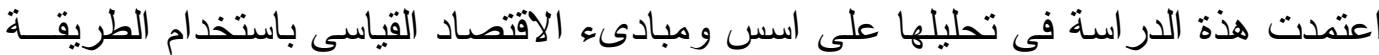

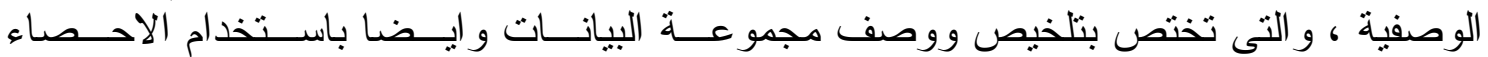

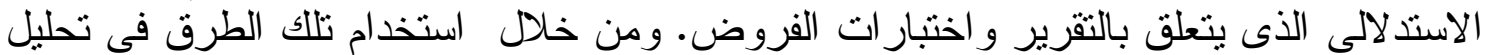

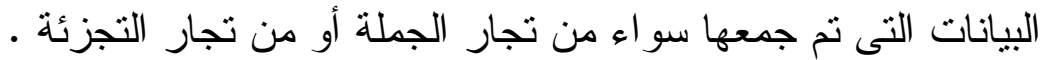

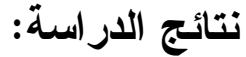

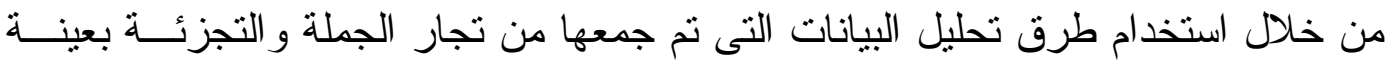

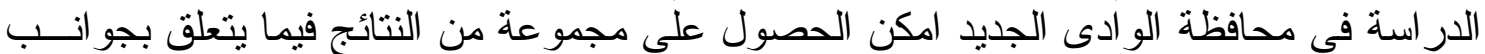

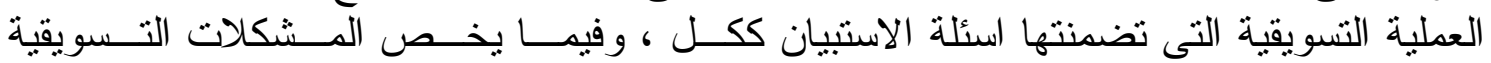

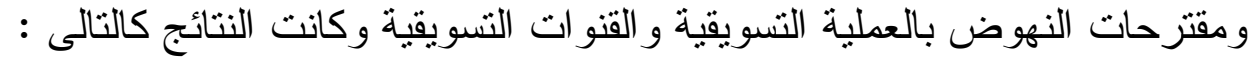

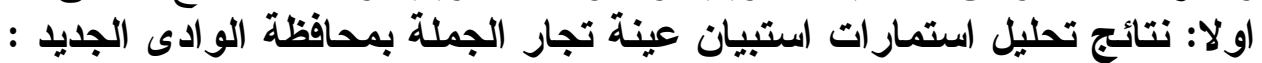

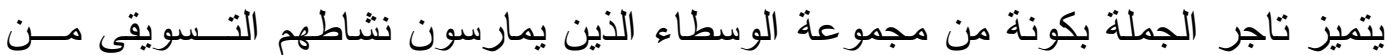

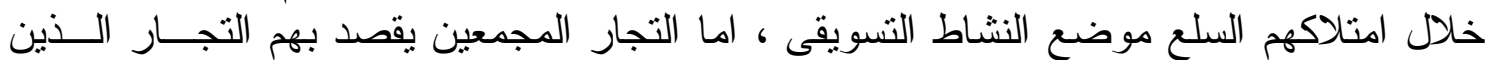

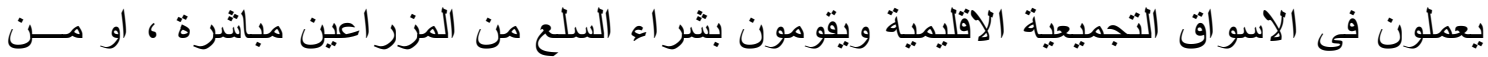

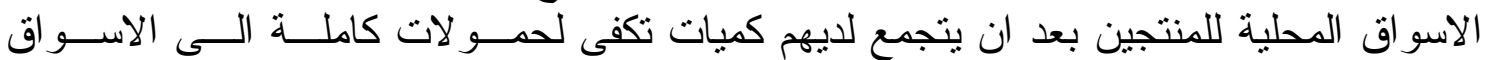

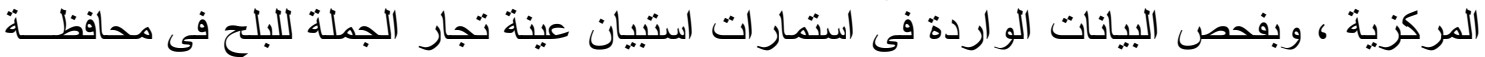

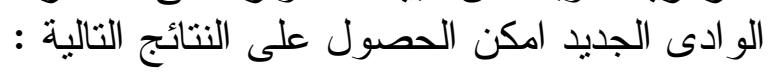

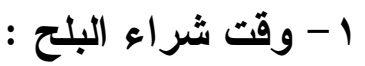

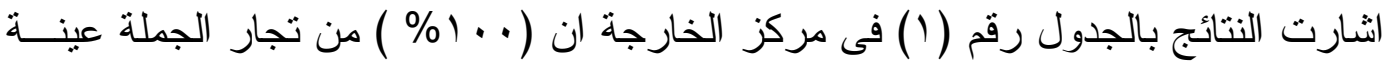

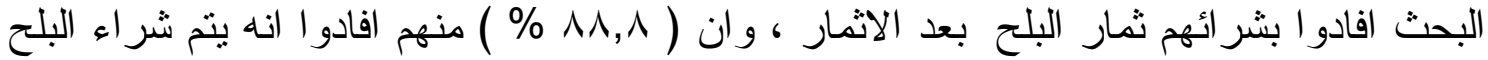

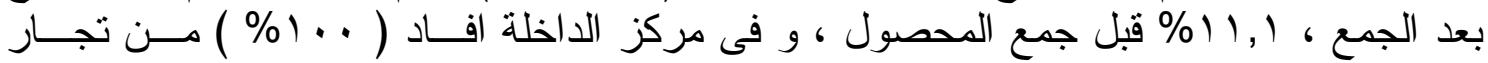

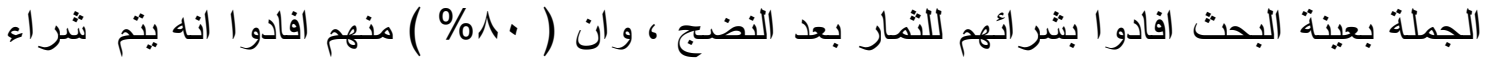

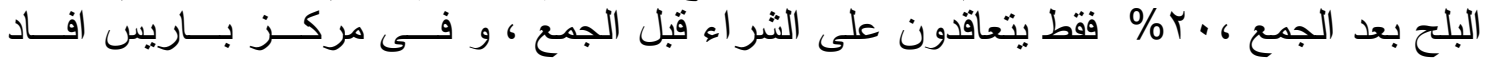

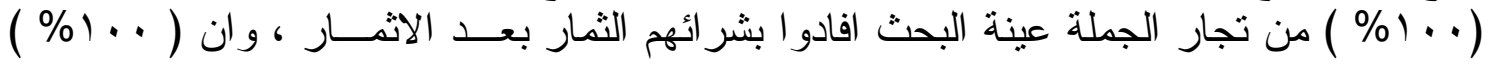

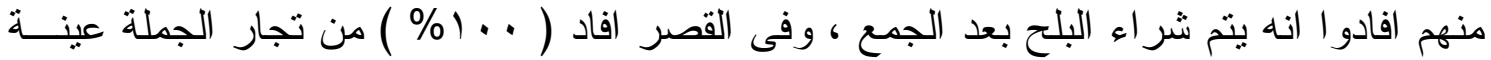

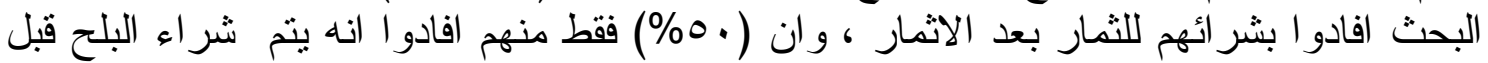




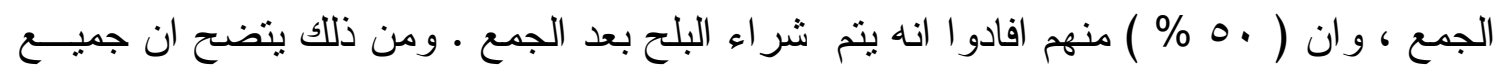

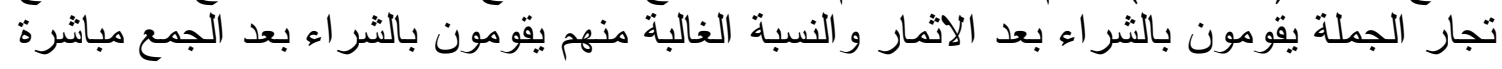

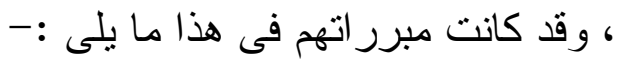

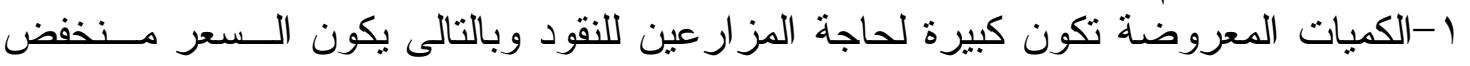
نسبيا ومناسب للتجار r-عدم تو افر مخازن صالحة لتخزين البلح و عدم تو افر الخبرات التخزينية لدى المز ارعين . جدول رقم (1): توزيع تجار الجملة فى عينة البحث بمحافظة الوادى الجديد وفقا لوقت شــراء ثمار البلح

\begin{tabular}{|c|c|c|c|c|c|c|c|}
\hline \multicolumn{4}{|c|}{ الشر اء بعد الاثمار } & \multirow{2}{*}{\multicolumn{2}{|c|}{ الشراء قبل الاثمـار }} & \multirow{3}{*}{ حجم العينة } & \multirow{3}{*}{ المنطقة } \\
\hline \multicolumn{2}{|c|}{ الثر اء قبل الجمع } & \multicolumn{2}{|c|}{ الثراء بعد الجمع } & & & & \\
\hline$\%$ & نعم & $\%$ & 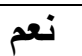 & $\%$ & نعم & & \\
\hline 11,1 & $r$ & $\wedge \wedge, \wedge$ & Tร & - & - & TV & الخارجة \\
\hline$r \cdot$ & $r$ & A. & Ir & - & - & 10 & الاخلة \\
\hline- & - & $1 \ldots$ & $\wedge$ & - & - & $\Lambda$ & باريس \\
\hline 0. & $\varepsilon$ & 0. & $\varepsilon$ & - & - & $\wedge$ & القصر \\
\hline$I V, Y$ & 1. & $\Lambda Y, \Lambda$ & $\varepsilon \wedge$ & - & - & $0 \wedge$ & الجمله \\
\hline
\end{tabular}

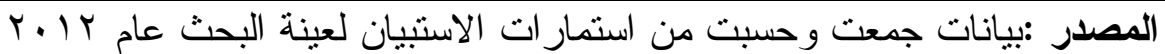
r -طريقة دفع التجار لثمن البلح:

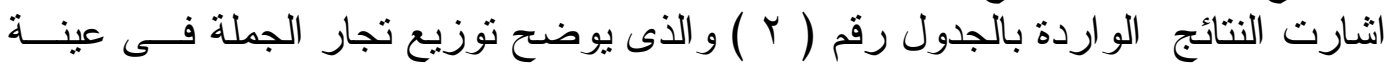

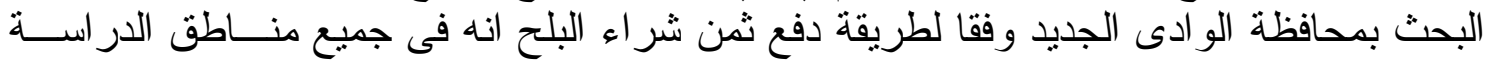

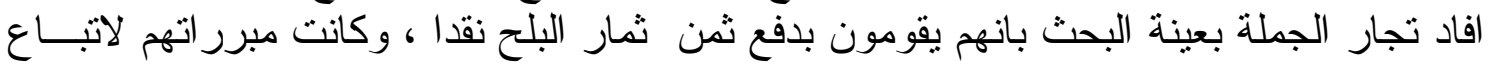

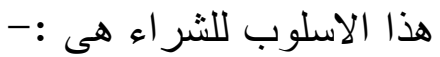
ا-عدم وجود نظام البيع بالاجل في مناطق الدراسة وان الاسلوب السائد هو التعامــل النقـــى فقط.

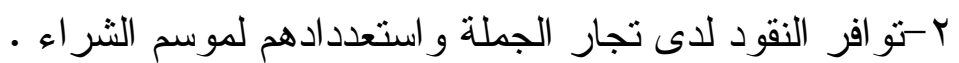

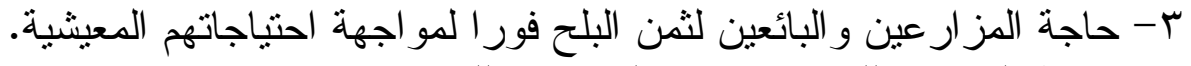

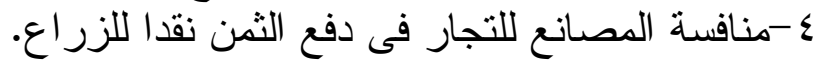

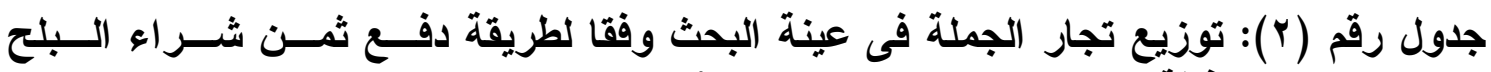

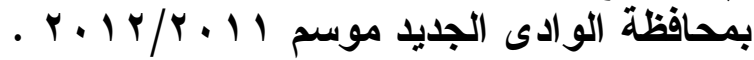

\begin{tabular}{|c|c|c|c|c|c|}
\hline \multicolumn{2}{|c|}{ الافع بالتقسيط } & \multicolumn{2}{|c|}{ الدفع نقدا } & \multirow{2}{*}{ حجم العينه } & \multirow{2}{*}{ المنطقة } \\
\hline$\%$ & نعم & $\%$ & نعم & & \\
\hline- & - & $1 \ldots$ & TV & TV & الخارجة \\
\hline- & - & $1 \ldots$ & 10 & 10 & الاخله \\
\hline- & - & $1 \ldots$ & $\Lambda$ & $\Lambda$ & باريس \\
\hline- & - & $1 \ldots$ & $\Lambda$ & $\Lambda$ & القصر \\
\hline- & - & $1 \ldots$ & $0 \wedge$ & $0 \wedge$ & حملة \\
\hline
\end{tabular}

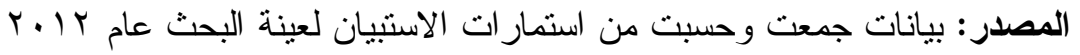

ب-نوع العبوات المستخدمة فى تعبئة ثمار البلح

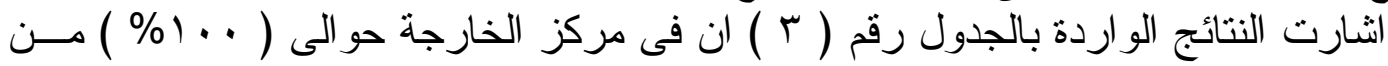

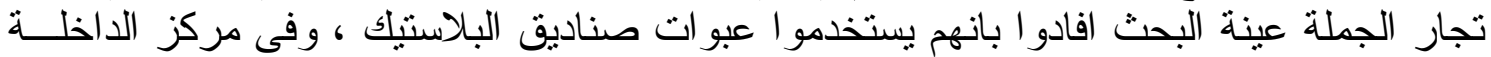

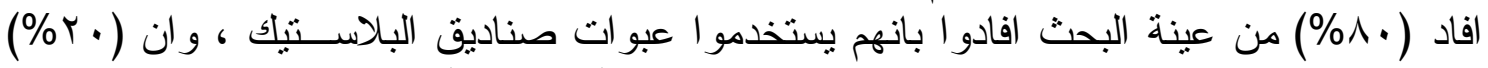

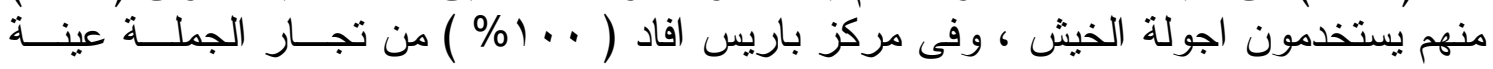




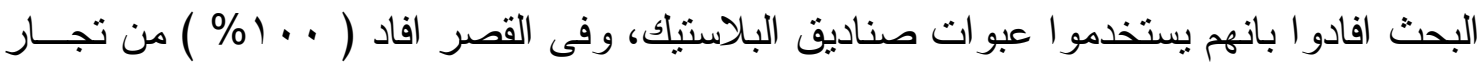

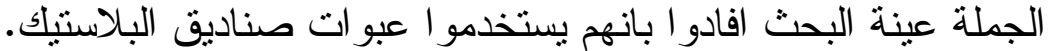

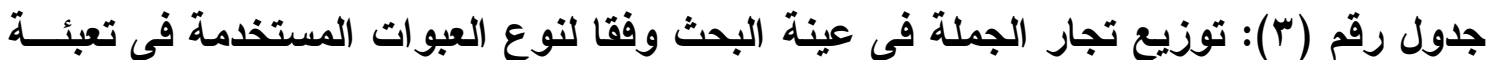

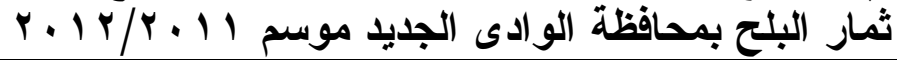

\begin{tabular}{|c|c|c|c|c|c|c|c|}
\hline$\%$ & اخرى & $\%$ & صناديق بلاستيك & $\%$ & اجولة & حجم العينه & عبوات \\
\hline & - & $1 \ldots$ & TV & - & - & TV & الخارجة \\
\hline & - & $\Lambda$. & Ir & $r$. & $r$ & 10 & الاخله \\
\hline & - & $1 \ldots$ & $\Lambda$ & - & - & $\Lambda$ & باريس \\
\hline & - & $1 \ldots$ & $\wedge$ & - & - & $\wedge$ & القصر \\
\hline & - & $9 \leqslant, \leqslant 0$ & 00 & 0,00 & $r$ & 01 & جمله \\
\hline
\end{tabular}

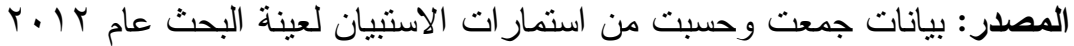

ع -مدى اجراء عملية فرز الثمار والمعايير التى تتم على التى اساسها:

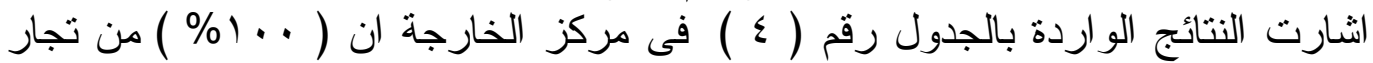

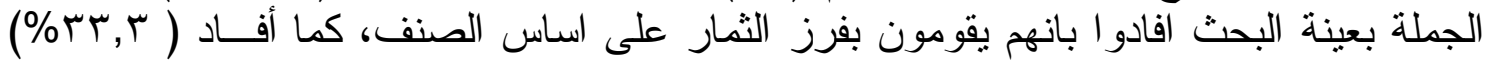

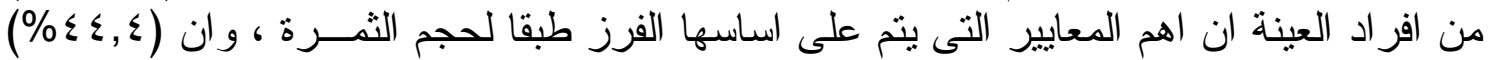

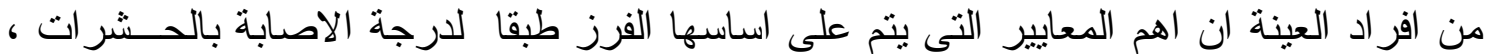

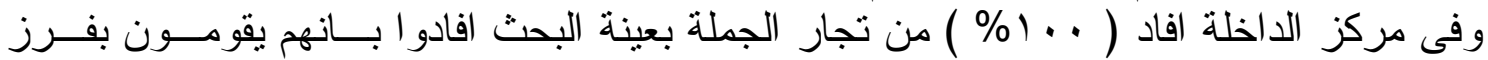

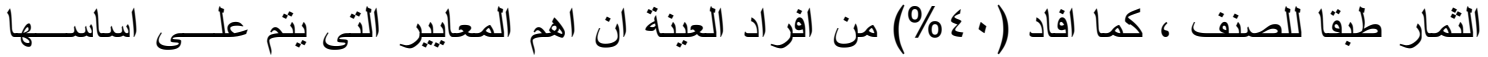

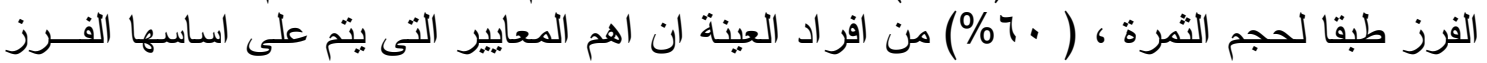

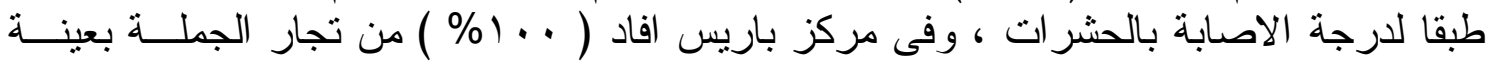

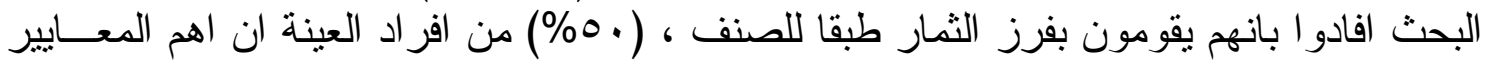

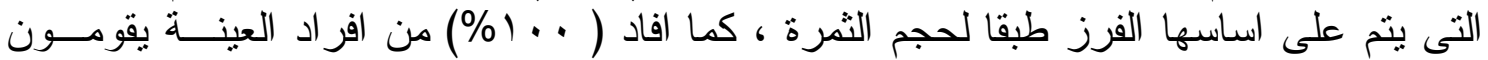

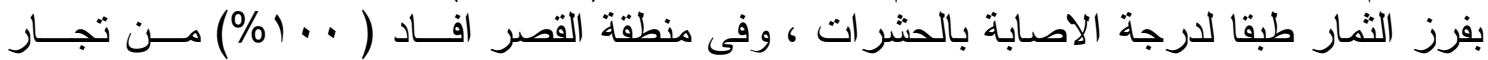

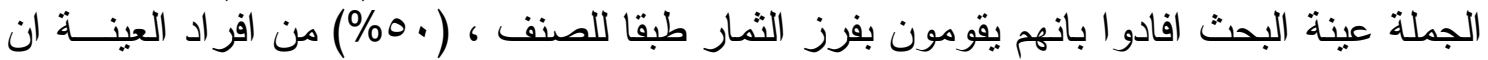

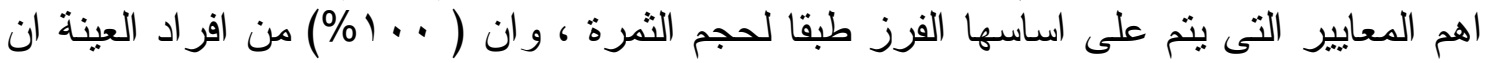

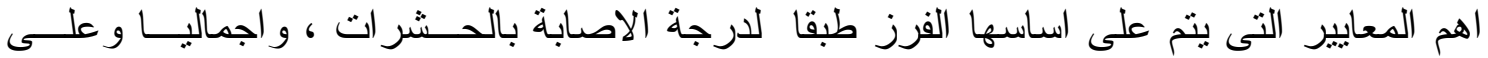

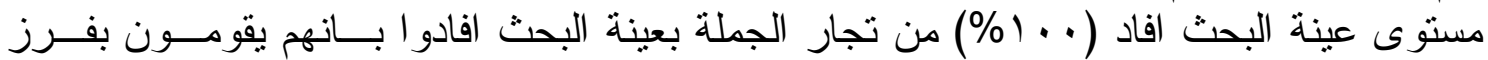

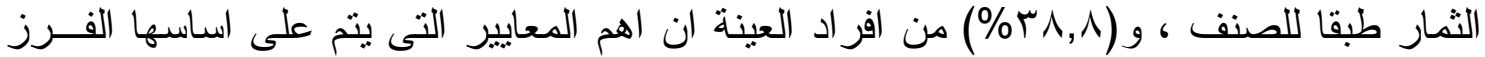

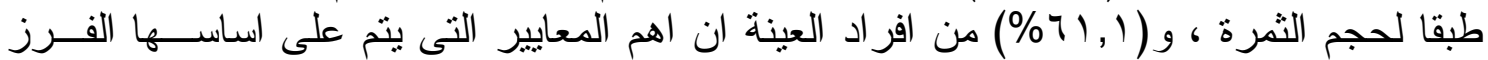
طبقا لارجة الاصابة بالحشرات.

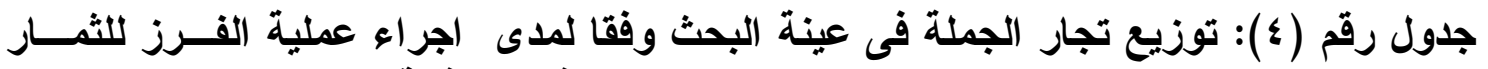

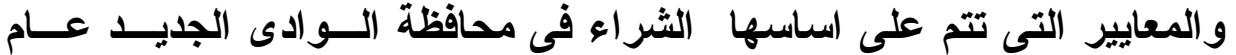

\begin{tabular}{|c|c|c|c|c|c|c|c|}
\hline \multicolumn{6}{|c|}{ نمم } & \multirow{2}{*}{ العينجة } & \multirow{2}{*}{ المنطقة } \\
\hline$\%$ & الاصابات الحشرية & $\%$ & حجم الثمرة & $\%$ & الصنف & & \\
\hline$\varepsilon \varepsilon, \varepsilon$ & Ir & rT, & 9 & $1 \ldots$ & YV & $r V$ & الخارجة \\
\hline 7. & 9 & $\varepsilon$. & 7 & $1 \ldots$ & 10 & 10 & الاخلها \\
\hline $1 \ldots$ & $\wedge$ & 0. & $\varepsilon$ & $1 \ldots$ & $\wedge$ & $\Lambda$ & باريس \\
\hline $1 \ldots$ & $\wedge$ & 0 . & $\varepsilon$ & $1 \ldots$ & $\wedge$ & $\Lambda$ & القصر \\
\hline $7 r, \vee q$ & rV & $r 9,70$ & rT & $1 \cdots$ & 01 & $0 \wedge$ & جملة \\
\hline
\end{tabular}

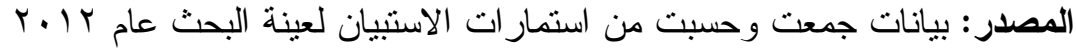


ه- مدى اجراء عمليات التخزين لثمار البلح واماكن تخزينها:

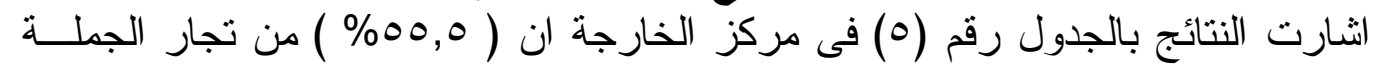

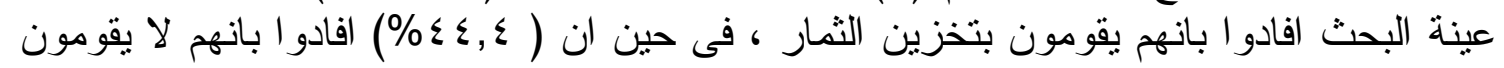

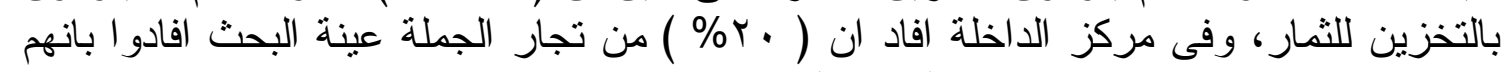

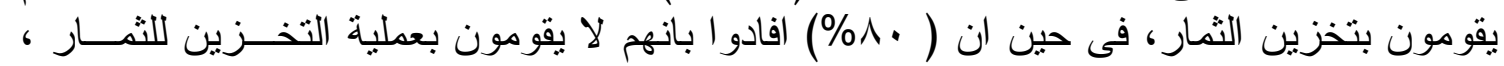

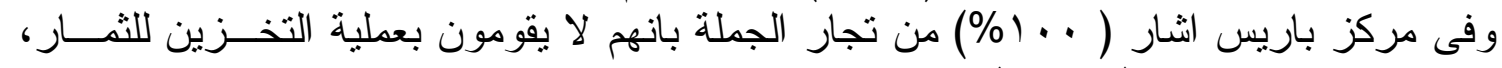

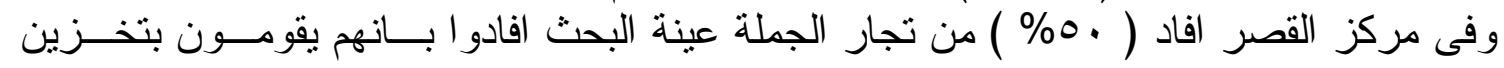

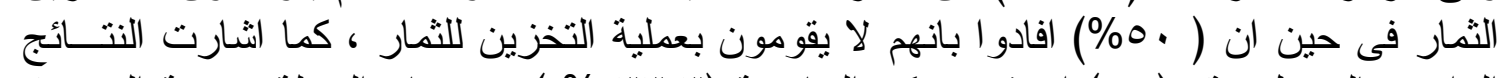

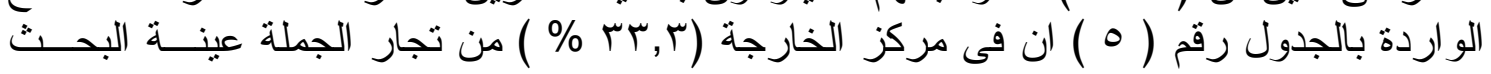

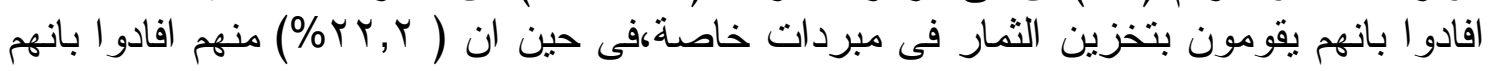

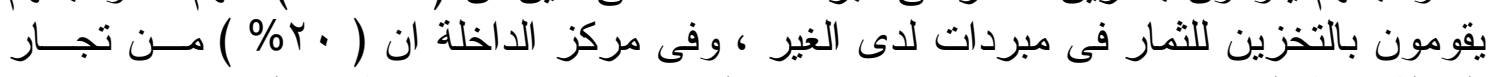

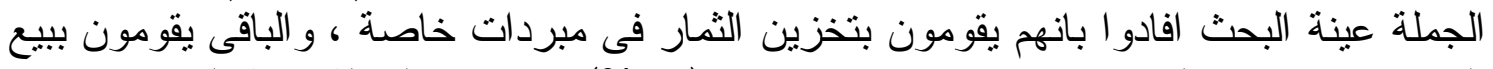

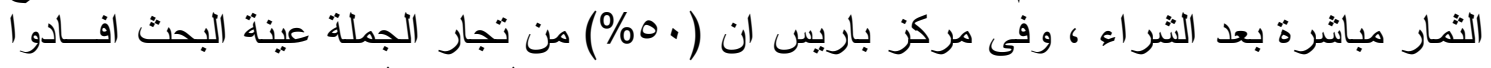

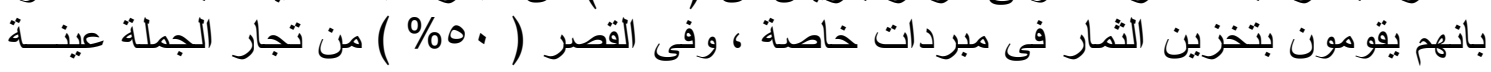

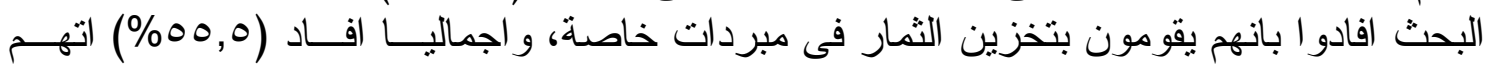

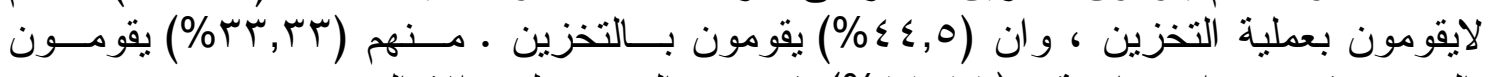

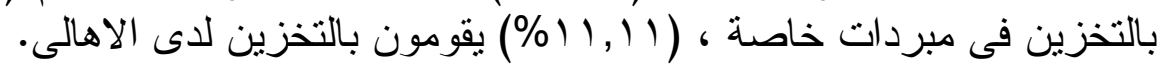

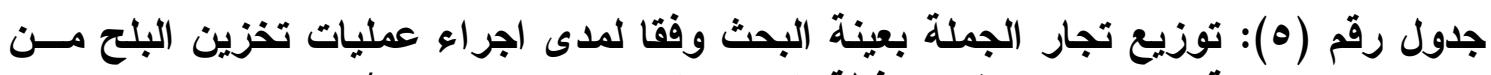

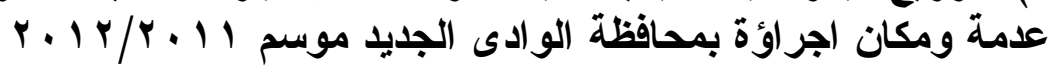

\begin{tabular}{|c|c|c|c|c|c|c|c|c|c|}
\hline \multicolumn{6}{|c|}{ تخزين الثمار قبل البيع } & \multicolumn{2}{|c|}{ عرض الثمار للبيع } & \multirow{2}{*}{ العينهة } & \multirow{2}{*}{ المنطقة } \\
\hline$\%$ & مخازن اهالى & $\%$ & خاصةن & $\%$ & حكومية & $\%$ & نعم & & \\
\hline$Y Y, Y$ & 7 & $r r, r$ & 9 & & - & $\varepsilon \Sigma, \Sigma$ & Ir & PV & الخارجة \\
\hline- & - & $r$. & $r$ & & - & $\Lambda$. & IT & 10 & الألاخله \\
\hline- & - & 0. & $\varepsilon$ & & - & $1 \ldots$ & $\Lambda$ & $\Lambda$ & باريس \\
\hline- & - & 0. & $\varepsilon$ & & - & 0. & $\varepsilon$ & $\Lambda$ & القصر \\
\hline $1 \cdot, \Gamma \leq$ & 7 & $r \varepsilon, \varepsilon$ & $r$. & & - & $7 r, \cdot 7$ & ru & $\Delta \Lambda$ & جملة \\
\hline
\end{tabular}

7 -مبررات بيع الثمار من قبل التجار مباشرة:

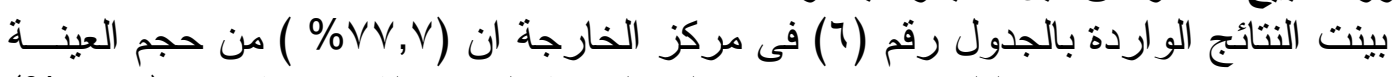

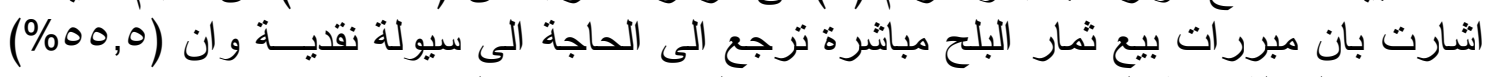

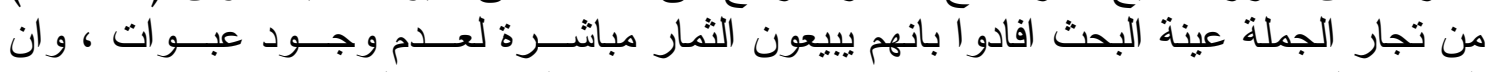

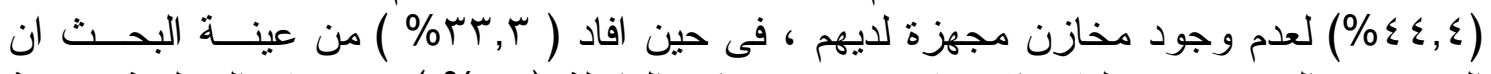

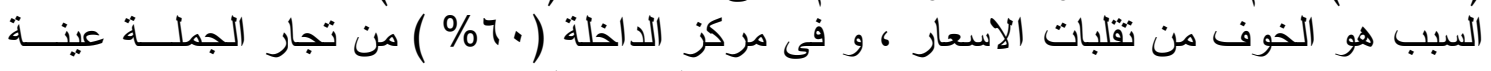

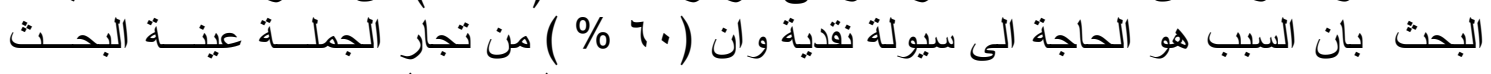

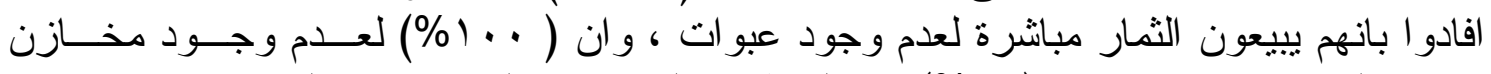

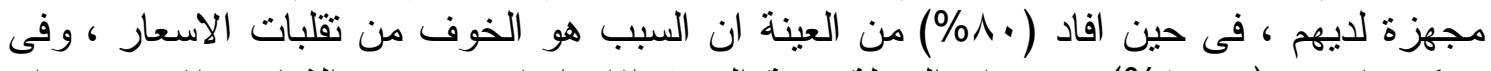

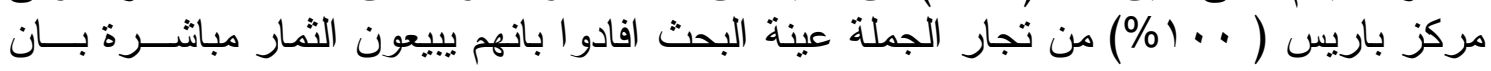

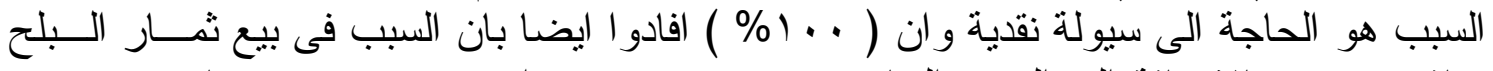

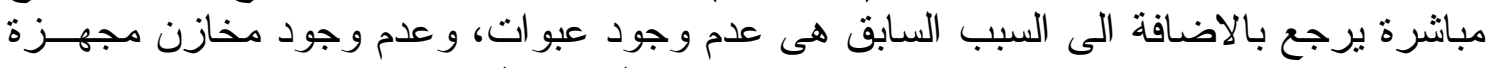

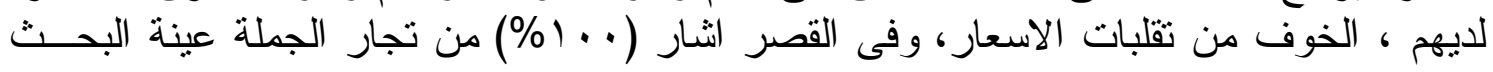




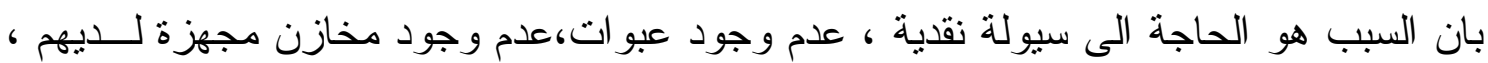

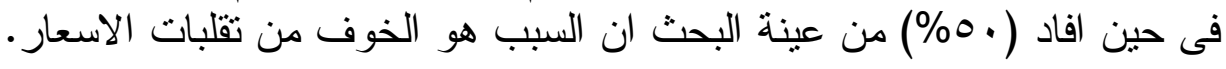

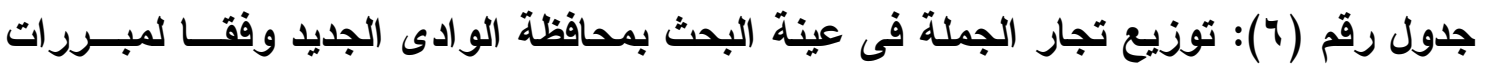

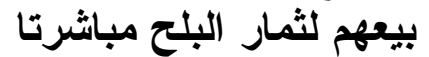

\begin{tabular}{|c|c|c|c|c|c|c|c|c|c|}
\hline \multicolumn{2}{|c|}{$\varepsilon$} & \multicolumn{2}{|c|}{$r$} & \multicolumn{2}{|c|}{$r$} & \multicolumn{2}{|c|}{1} & \multirow{2}{*}{ حجم العينه } & \multirow{2}{*}{ المنطقة } \\
\hline$\%$ & نعم & $\%$ & نعم & $\%$ & نعم & $\%$ & نعم & & \\
\hline r & 9 & $\varepsilon \varepsilon, \varepsilon$ & IT & 00,0 & 10 & $V \vee, V$ & YI & YV & الخارجة \\
\hline ᄉ. & Ir & $1 \ldots$ & 10 & 7. & 9 & 7. & 9 & 10 & اللاخلة \\
\hline $1 \ldots$ & $\wedge$ & $1 \ldots$ & $\wedge$ & $1 \ldots$ & $\wedge$ & $1 \ldots$ & $\wedge$ & $\Lambda$ & باريس \\
\hline 0 . & $\varepsilon$ & $1 \ldots$ & $\wedge$ & $1 \ldots$ & $\Lambda$ & $1 \ldots$ & $\wedge$ & $\Lambda$ & القصر \\
\hline 07,1 & r & $V \varepsilon, 1$ & $\varepsilon r$ & $7 \wedge, 9$ & $\varepsilon$. & $\vee ৭, \Gamma$ & $\leqslant 7$ & $0 \wedge$ & جملة \\
\hline
\end{tabular}

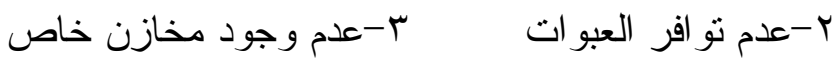

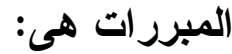

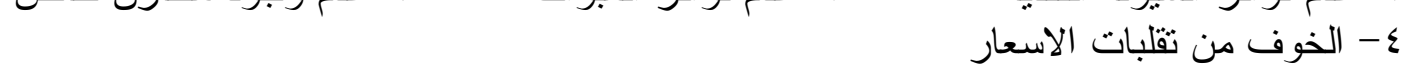

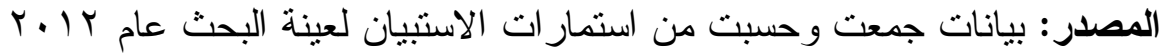
V-الهدف من التخزين لثمار البلح:

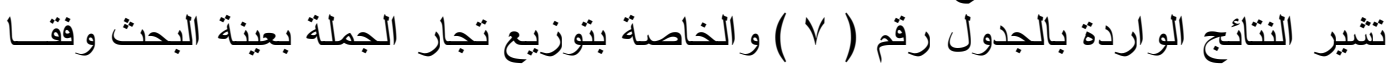

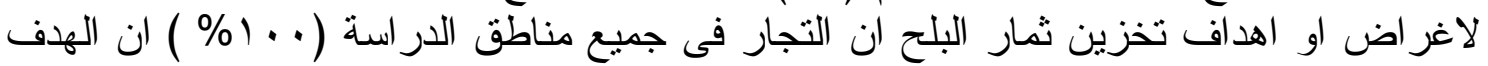
او الغرض تخزين الثمار الحصول على سعر مرتفع لهذة السلعة. جدول رقم (V): توزيع تجار الجملة بعينة البحث وفقا لاهداف او اغـــ اض تخــزينهم للـبلح

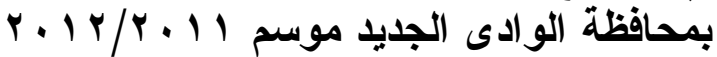

\begin{tabular}{|c|c|c|c|c|c|c|c|}
\hline$\%$ & في المحصود فائض & $\%$ & توقع تحسن & $\%$ & تحسين صفات & حجم العينه & الهُف \\
\hline & - & $1 \ldots$ & TV & & - & $r V$ & الخارجه \\
\hline & - & $1 \ldots$ & 10 & & - & 10 & الاخلها \\
\hline & - & $1 \ldots$ & $\Lambda$ & & - & $\Lambda$ & باريس \\
\hline & - & $1 \cdots$ & $\Lambda$ & & - & $\Lambda$ & القصر \\
\hline & - & $1 \ldots$ & 01 & & - & $0 \wedge$ & جمله \\
\hline
\end{tabular}

المصدر: بيانات جمعت وحسبت من استمار ات الاستبيان لعينة البحث عام / | .

\section{^- مدى وجود مشكلات فى تخزين ثمار البلح ونوعيتها:}

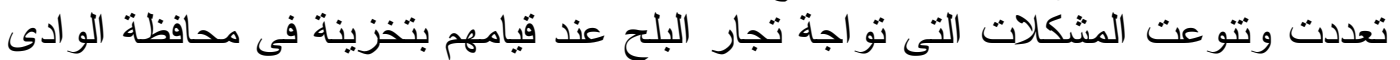

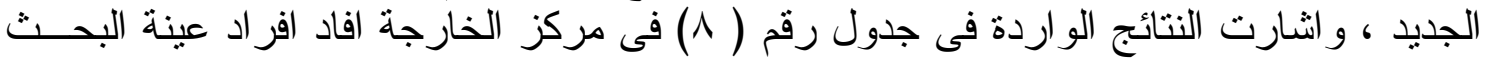

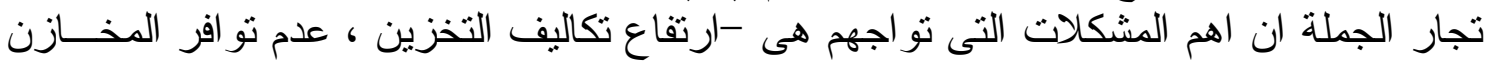

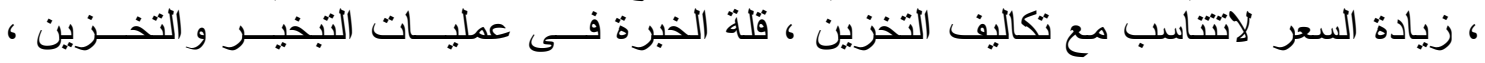

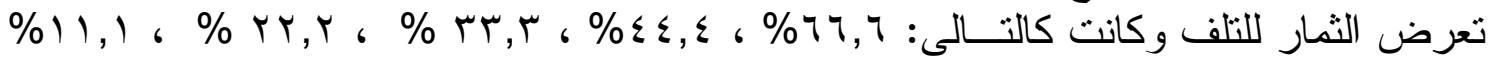
للمشكلات السابق الاشارة اليها على الترتيب. اما فى مركز الداخلة فقد ذكر تجار الجملة ان الهم

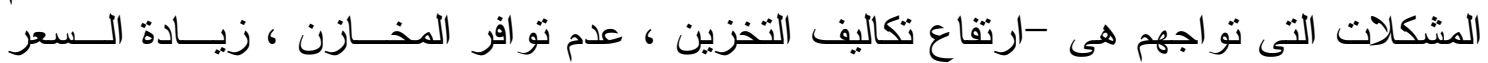

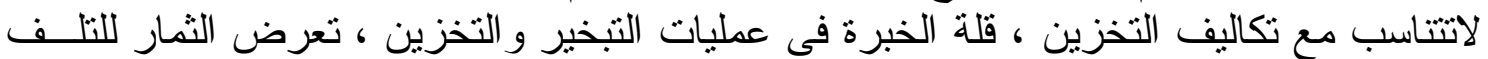

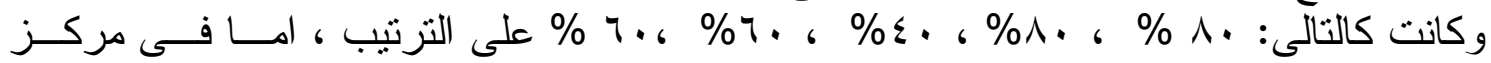

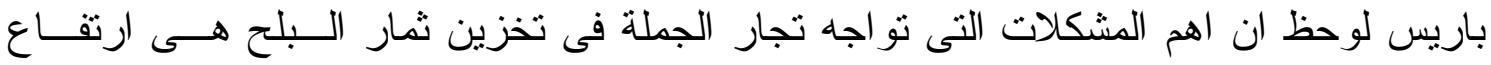




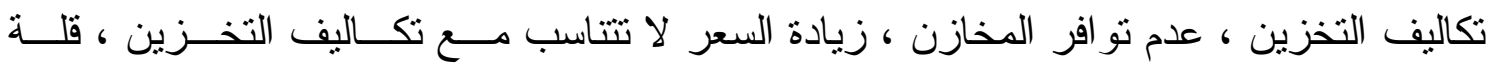

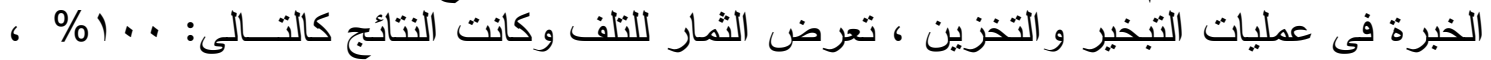

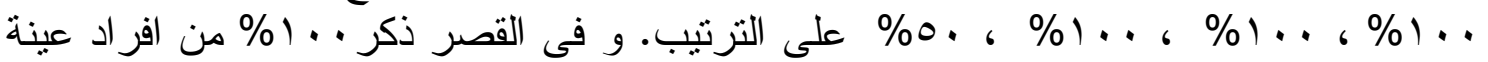

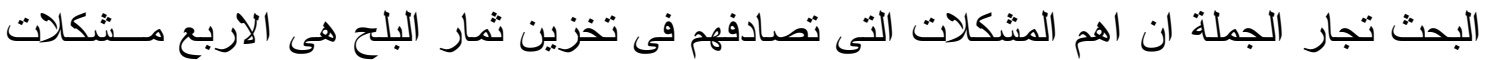

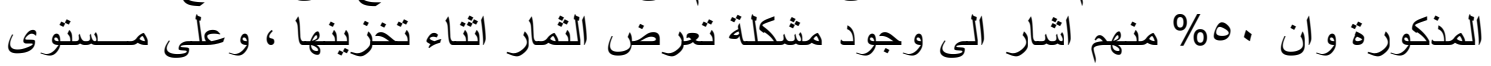

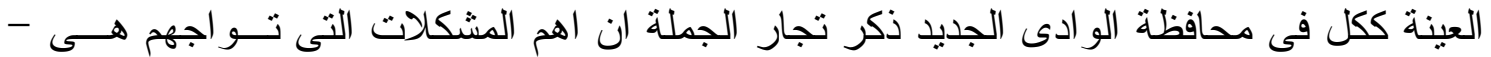

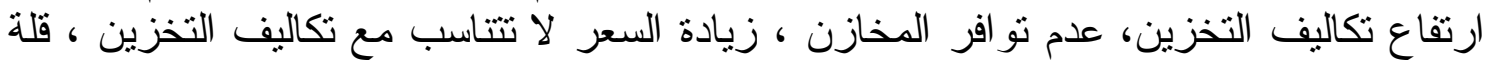

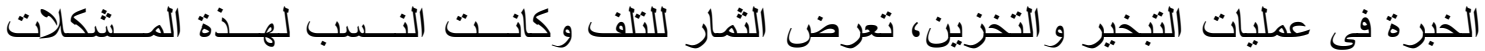

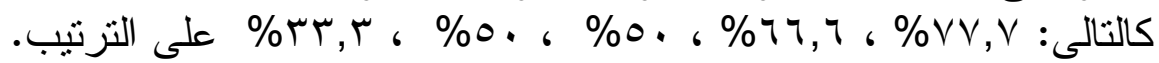

جدول رقم (^): توزيع تجار الجملة فى عينة البحث بمحافظة الوادى الجديد وفقا لمدى وجــود مشكلات فى تخزينهم لثمار البلح

\begin{tabular}{|c|c|c|c|c|c|c|c|c|c|c|c|}
\hline \multicolumn{2}{|c|}{0} & \multicolumn{2}{|c|}{$\varepsilon$} & \multicolumn{2}{|c|}{$r$} & \multicolumn{2}{|c|}{ r } & \multicolumn{2}{|c|}{1} & \multirow{2}{*}{ العينه } & \multirow{2}{*}{ المنطقة } \\
\hline$\%$ & نعم & $\%$ & نعم & $\%$ & نعم & $\%$ & نعم & $\%$ & نعم & & \\
\hline 11.1 & $r$ & $Y Y, Y$ & 7 & r r & 9 & $\leqslant \varepsilon_{6} \varepsilon$ & IT & 77.7 & 11 & YV & الخارجة \\
\hline 7. & 9 & 7. & 9 & $\varepsilon$. & 7 & $\Lambda$. & IT & $\Lambda$. & IT & 10 & الداخلة \\
\hline 0 . & $\varepsilon$ & $1 \ldots$ & $\Lambda$ & $1 \ldots$ & $\Lambda$ & $1 \ldots$ & $\Lambda$ & $1 \ldots$ & $\wedge$ & $\Lambda$ & باريس \\
\hline 0 . & $\varepsilon$ & $1 \ldots$ & $\wedge$ & $1 \ldots$ & $\Lambda$ & $1 \ldots$ & $\Lambda$ & $1 \ldots$ & $\Lambda$ & $\Lambda$ & القصر \\
\hline$r \leqslant, 0$ & $r$. & or, z & T & 0. & TV & 71,9 & $\varepsilon$. & $V q, r$ & $\leqslant 7$ & $0 \wedge$ & اجمالى \\
\hline
\end{tabular}

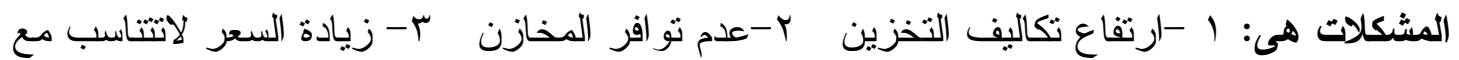

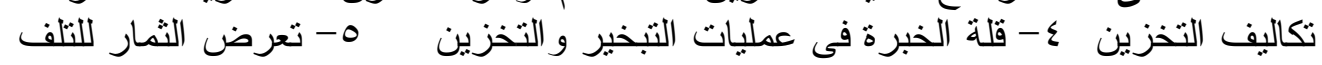

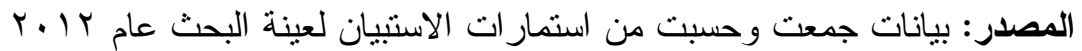

9 -العمليات التى تجرى على ثمار البلح قبل التخزين:

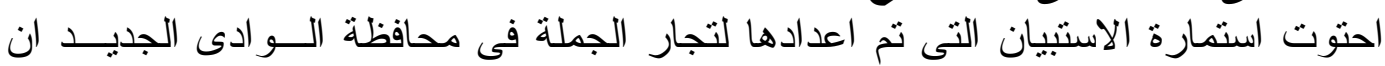

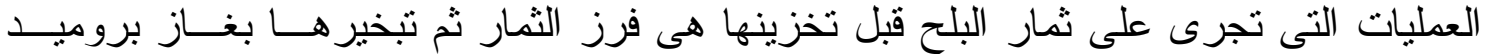

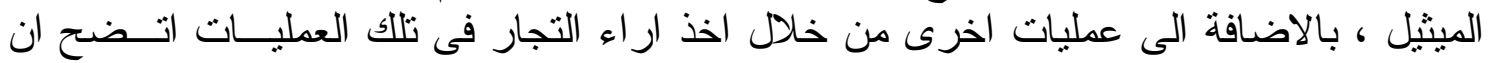

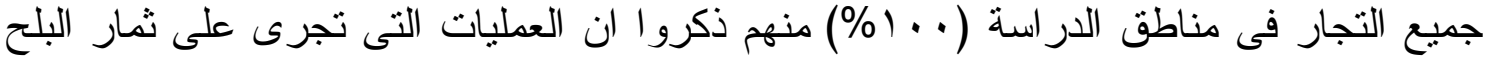

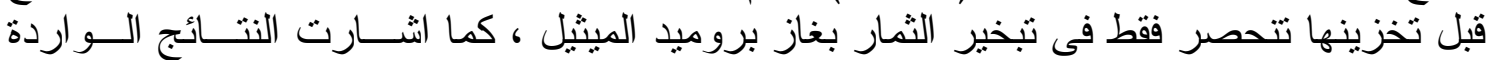

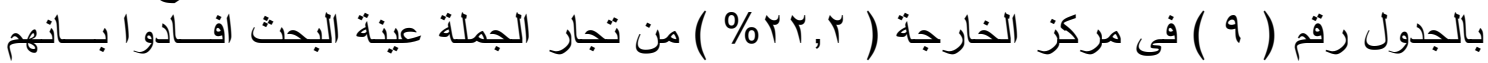

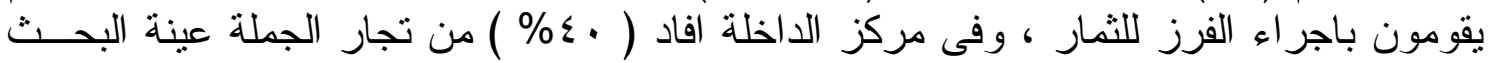

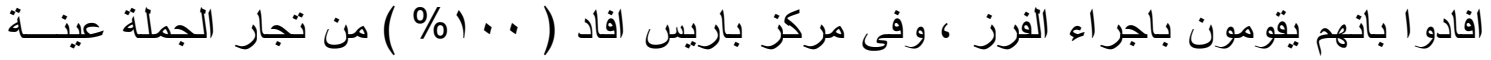

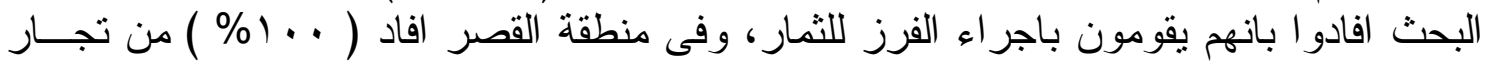

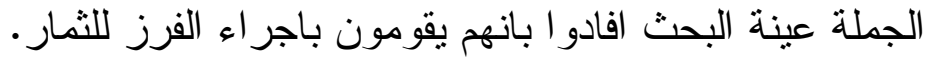

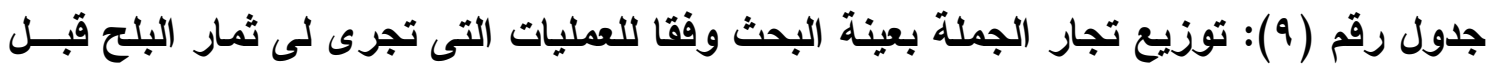

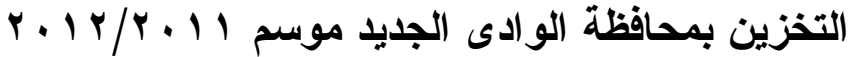

\begin{tabular}{|c|c|c|c|c|c|c|c|c|c|}
\hline$\%$ & عمليات & $\%$ & بروميد الميشيل & $\%$ & غسيل & $\%$ & فرز الثمار & العينه & العملية \\
\hline- & - & $1 \ldots$ & $r V$ & - & - & $Y Y, Y$ & 7 & TV & الخارجة \\
\hline- & - & $1 \ldots$ & 10 & - & - & $\varepsilon$ & 7 & 10 & الا/خله \\
\hline- & -- & $1 \ldots$ & $\Lambda$ & - & - & $1 \ldots$ & $\Lambda$ & $\Lambda$ & باريس \\
\hline- & -- & $1 \ldots$ & $\wedge$ & - & - & $1 \ldots$ & $\wedge$ & $\Lambda$ & القصر \\
\hline- & - & $1 \ldots$ & 01 & - & - & $\varepsilon \Lambda, Y \vee$ & TA & $0 \wedge$ & الجملة \\
\hline
\end{tabular}

المصدر: بيانات جمعت وحسبت من استمار ات الاستبيان لعينة البحث عام 
. 1 - مدى وجود اعباء مالية على التجار ونوعها :

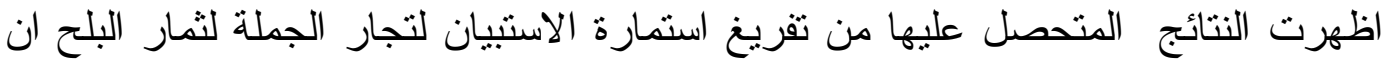

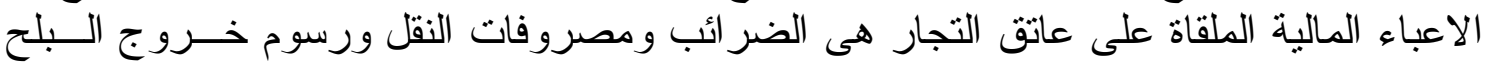

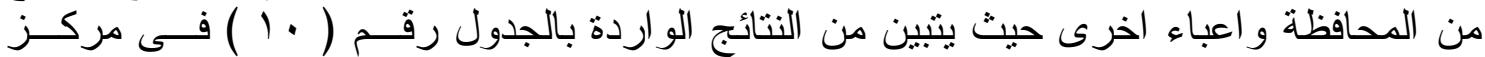

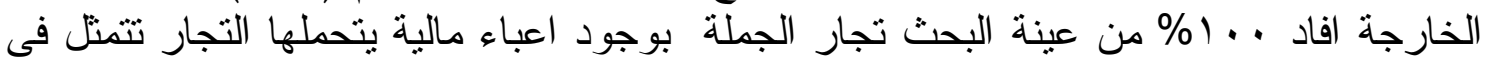

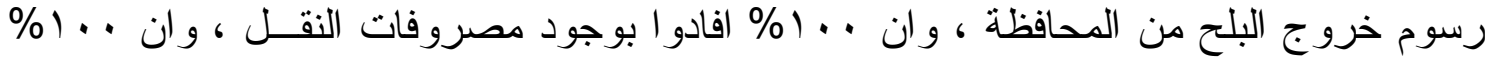

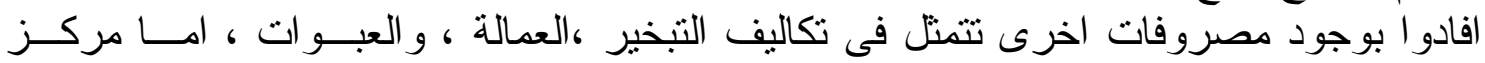

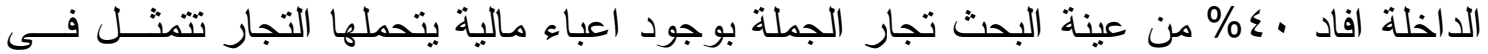

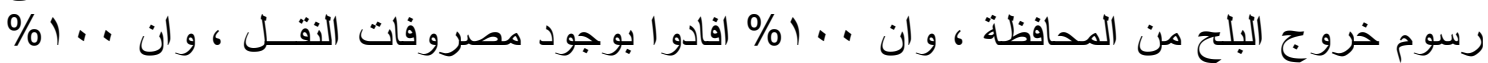

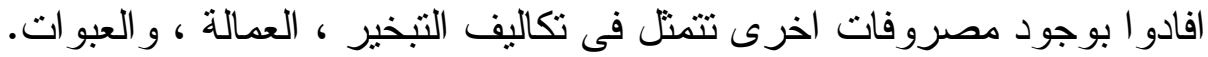

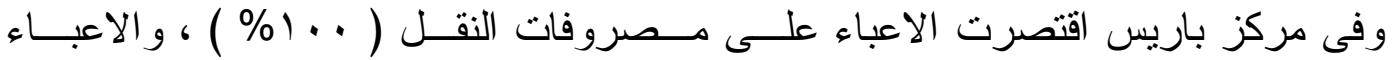

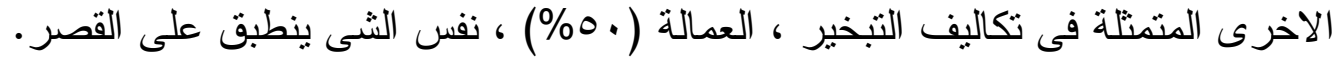

جدول رقم ( • 1) توزيع تجار الجملة فى عينة البحث بمحافظة الوادى الجديا وفقا لمدى وجود اعباء مالية يتحملونها ونوع هذة الاعباء

\begin{tabular}{|c|c|c|c|c|c|c|c|c|c|}
\hline \multicolumn{8}{|c|}{ نعم } & \multirow[b]{2}{*}{ العينه } & \multirow[b]{2}{*}{ المنطقة } \\
\hline$\%$ & اخرى اعباء & $\%$ & محلية & $\%$ & مصروفات & $\%$ & الضر ائب & & \\
\hline $1 \cdots$ & TV & $1 \cdots$ & KV & $1 \ldots$ & TV & $r, Y$ & 7 & $r V$ & الخارجة \\
\hline $1 \ldots$ & 10 & $\varepsilon$. & 7 & $1 \ldots$ & 10 & $r$. & $r$ & 10 & الاداخلة \\
\hline 0. & $\varepsilon$ & - & - & $1 \ldots$ & $\wedge$ & & - & $\Lambda$ & باريس \\
\hline 0. & $\varepsilon$ & - & - & $1 \ldots$ & $\wedge$ & & - & $\Lambda$ & القصر \\
\hline$\Lambda \neg, r$ & 0. & 07,1 & r & $1 \ldots$ & $0 \wedge$ & 10,0 & 9 & $\Delta \wedge$ & جملة \\
\hline
\end{tabular}

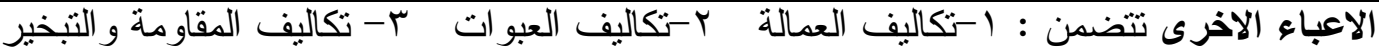
المصدر: بيانات جمعت وحسبت من استمار ات الاستبيان لعينة البحث عام ب ا . ب

\section{1 ا - القتوات التسويقية المتبعة فى تسويق ثمار البلح:}

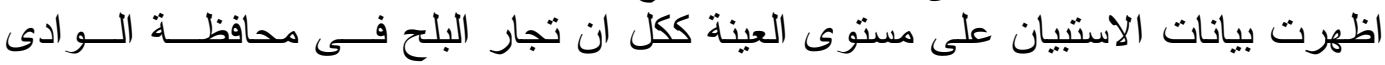

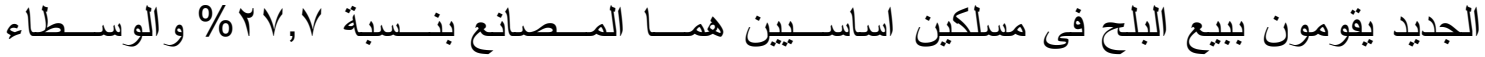

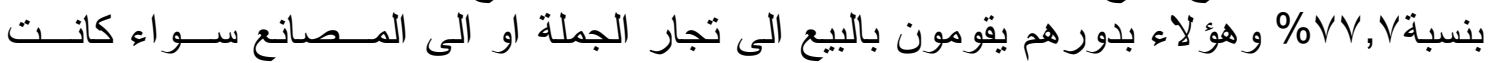

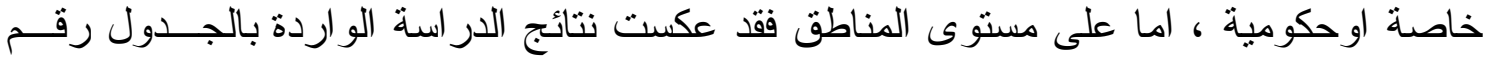

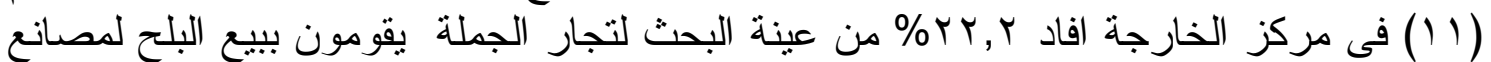

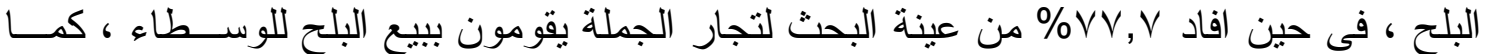

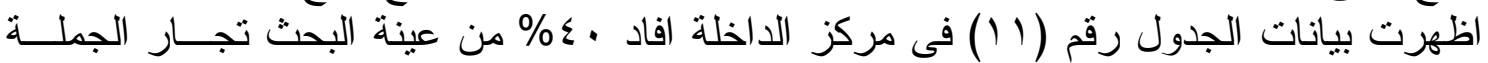

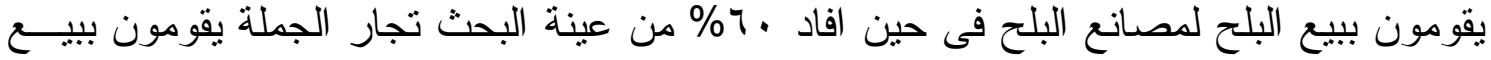

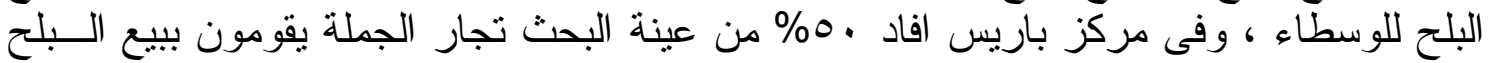

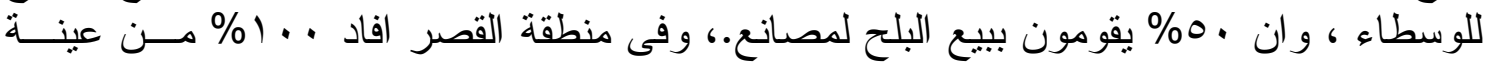
البحث تجار الجملة انهم يقومون ببيع البلح الى الى الوسطاء.

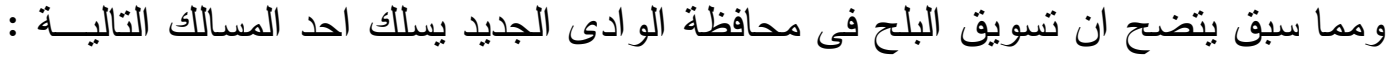

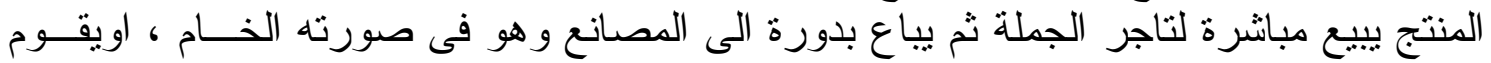

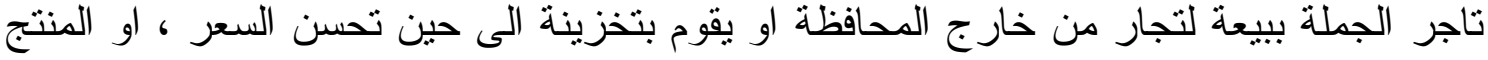

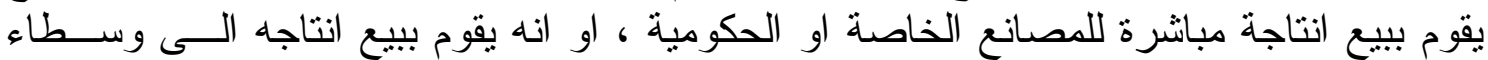
تقوم بدور ها ببيعه لتجار الجملة او الى المصانع كما هو موضع بالثكل التخطيطى (شكل رقم ا ) 


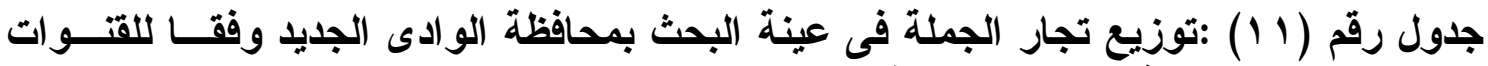

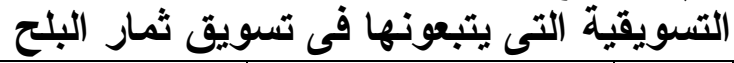

\begin{tabular}{|c|c|c|c|c|c|c|c|c|c|c|c|c|c|}
\hline \multicolumn{2}{|c|}{ المستثهلك } & \multicolumn{2}{|c|}{ المصانع } & \multicolumn{4}{|c|}{ الوسطاء } & \multicolumn{4}{|c|}{ تجار التجزئة } & \multirow{2}{*}{ العينه } & \multirow{2}{*}{ المنطقة } \\
\hline$\%$ & 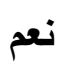 & $\%$ & 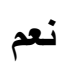 & $\%$ & ע & $\%$ & 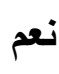 & $\%$ & بالاجل & $\%$ & نقدا & & \\
\hline & - & \%YY,Y & 7 & - & - & $V \vee, V$ & YI & - & - & - & - & YV & الخارجة \\
\hline & - & $\varepsilon$. & 7 & - & - & 7. & 9 & - & - & - & - & 10 & الاخلة \\
\hline & - & 0. & $\varepsilon$ & - & - & 0. & $\varepsilon$ & - & - & - & - & $\Lambda$ & باريس \\
\hline & - & - & - & - & - & $1 \cdots$ & $\Lambda$ & - & - & - & - & $\Lambda$ & القصر \\
\hline & - & $\% Y V, 0$ & 17 & - & - & $V Y, \varepsilon$ & $\sum Y$ & - & - & - & - & $0 \wedge$ & جملة \\
\hline
\end{tabular}

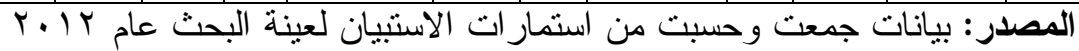

شكل رقم (1) توصيف المسلك التسويقى للبلح فى محافظة الوادى الجديد كالتالى :

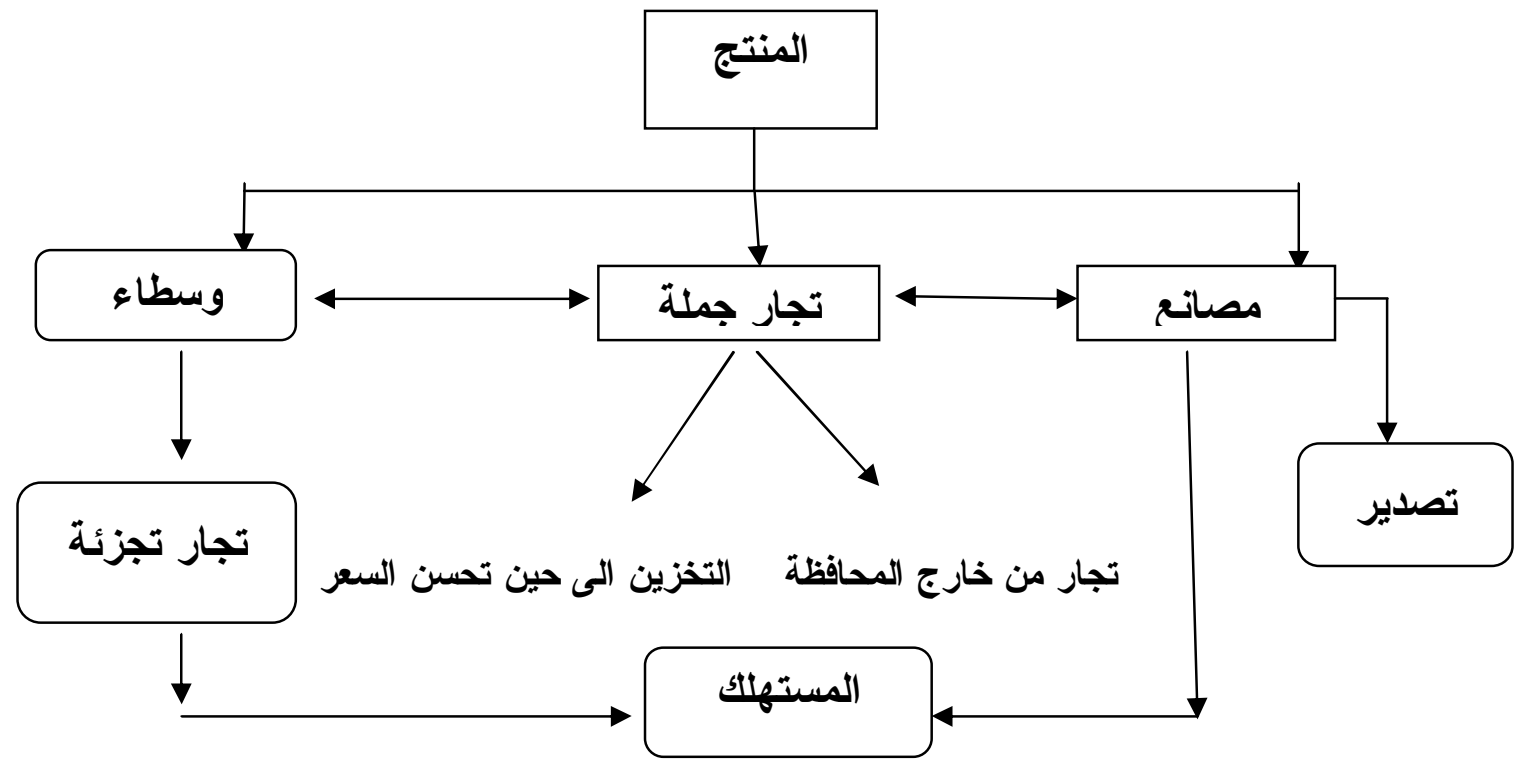

r ا إمقترحات النهوض بتسويق البلح:

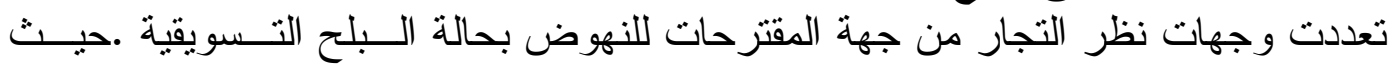

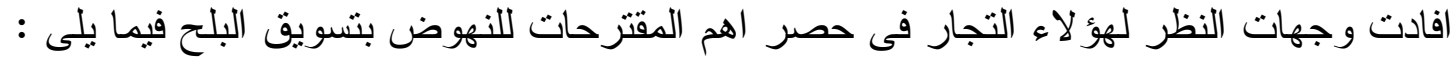

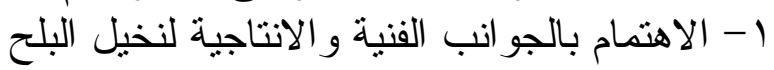

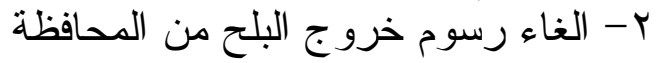

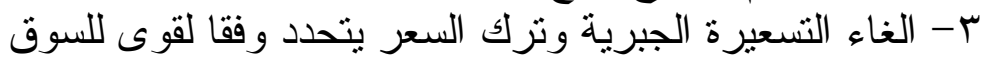

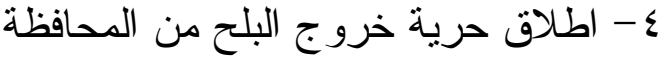

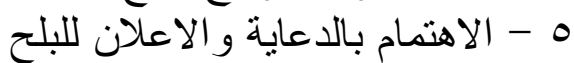

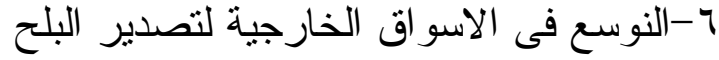

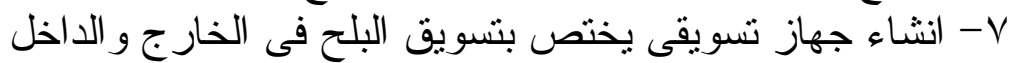

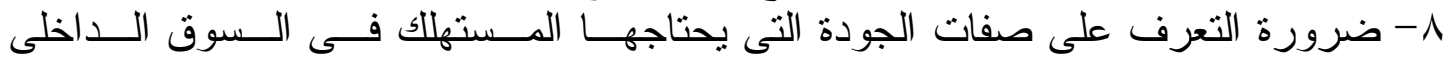
9- اقامة معارض خار ج المحافظة فى محافظات اخرى 
جدول رقم (r I ) :مقترحات النهوض بتسويق البلح من وجهة نظر تجار الجملــة فــى عينــة البحث بمحافظة الوادى الجليات

\begin{tabular}{|c|c|c|c|c|c|c|c|c|c|c|c|c|c|c|c|c|c|c|c|}
\hline \multicolumn{2}{|c|}{9} & \multicolumn{2}{|l|}{$\Lambda$} & \multicolumn{2}{|c|}{ V } & \multicolumn{2}{|c|}{7} & \multicolumn{2}{|c|}{0} & \multicolumn{2}{|c|}{$\varepsilon$} & \multicolumn{2}{|c|}{$r$} & \multicolumn{2}{|c|}{ r } & \multicolumn{2}{|c|}{1} & \multirow{2}{*}{ |لعينه } & \multirow{2}{*}{ المنطقة } \\
\hline$\%$ & عدد & $\%$ & عدد & $\%$ & عدد & $\%$ & عدد & $\%$ & عدد & $\%$ & عدد & $\%$ & عدد & $\%$ & عدد & $\%$ & عدد & & \\
\hline $1 \ldots$ & $r V$ & $1 \ldots$ & $T V$ & $\wedge \wedge, \wedge$ & $r \varepsilon$ & $V V, V$ & rI & r,r & 9 & $1 \ldots$ & TV & $\varepsilon \varepsilon, \varepsilon$ & IT & $1 \ldots$ & TV & 00,0 & 10 & $r V$ & الخارجة \\
\hline 7. & 9 & A. & IT & $\varepsilon$. & 7 & $\varepsilon$. & 7 & $\varepsilon$. & 7 & $1 \ldots$ & 10 & 7. & 9 & $1 \ldots$ & 10 & ^. & Ir & 10 & الا اخلة \\
\hline 0. & $\varepsilon$ & $1 \ldots$ & $\wedge$ & 0. & $\varepsilon$ & 0. & $\varepsilon$ & 0 . & $\varepsilon$ & $1 \ldots$ & $\wedge$ & $1 \ldots$ & $\wedge$ & $1 \ldots$ & $\wedge$ & 0. & $\varepsilon$ & $\Lambda$ & باريس \\
\hline 0. & $\varepsilon$ & 0. & $\varepsilon$ & $1 \ldots$ & $\wedge$ & 0 . & $\varepsilon$ & - & - & $1 \ldots$ & $\wedge$ & 0 . & $\varepsilon$ & $1 \ldots$ & $\wedge$ & 0 . & $\varepsilon$ & $\Lambda$ & القصر \\
\hline$\vee 0, \lambda$ & $\varepsilon \varepsilon$ & AV, $q$ & 01 & $V Y, \Sigma$ & $\varepsilon r$ & $7 \cdot r$ & ro & ז,ז" & 19 & $1 \ldots$ & 01 & 07,1 & זr & $1 \ldots$ & $0 \wedge$ & $7 \cdot \pi$ & ro & $0 \wedge$ & جملة \\
\hline
\end{tabular}

1 - الاهتمام بالجو انب الفنية و الانتاجية لنخيل البلح

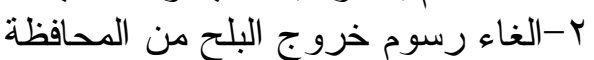

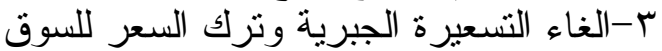

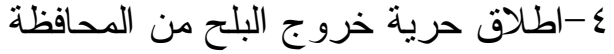

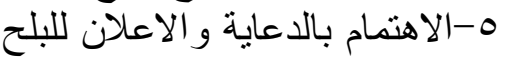

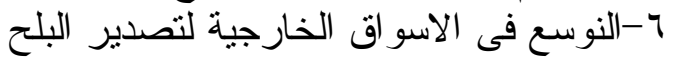

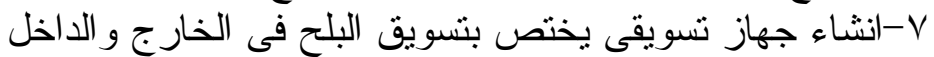

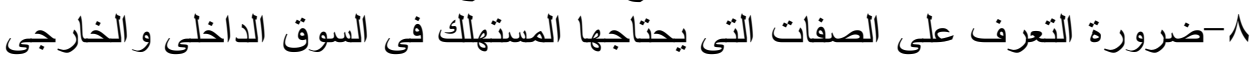

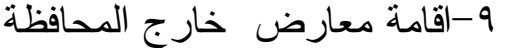

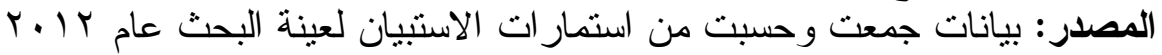

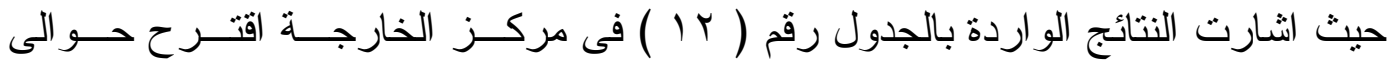

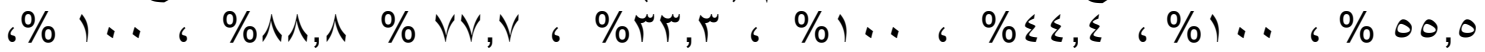

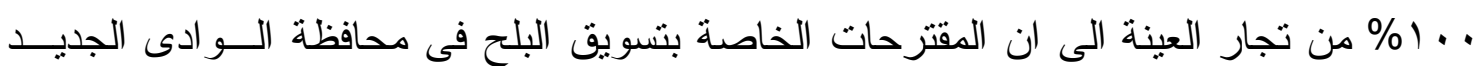

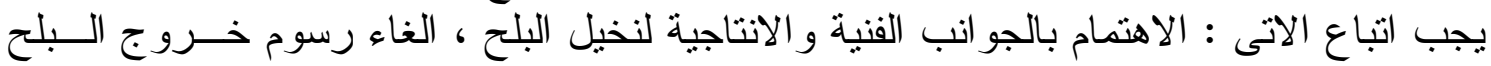

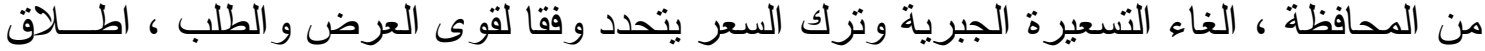

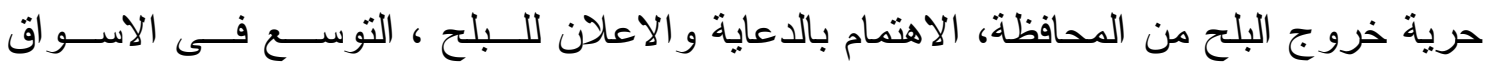

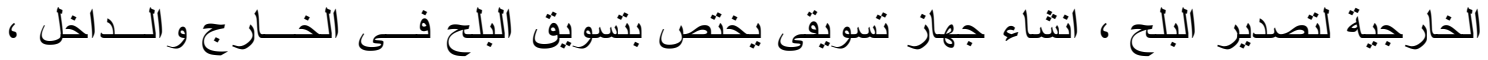

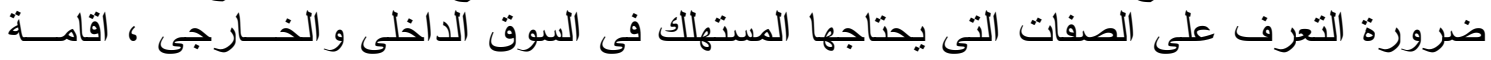

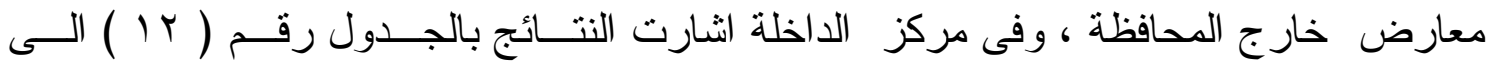

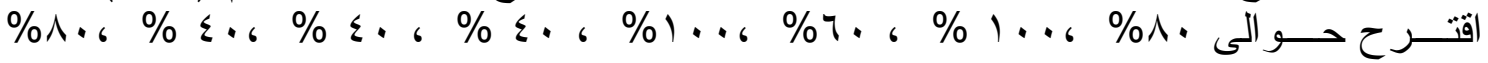

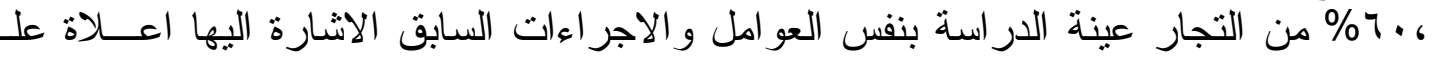

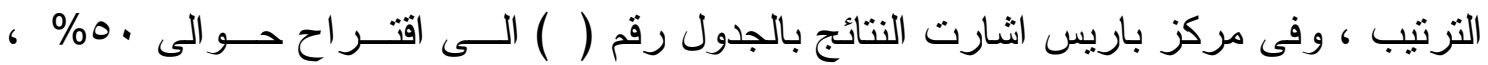

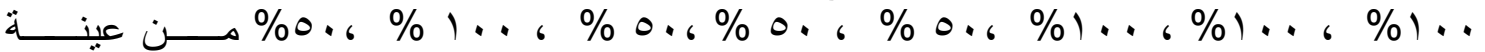

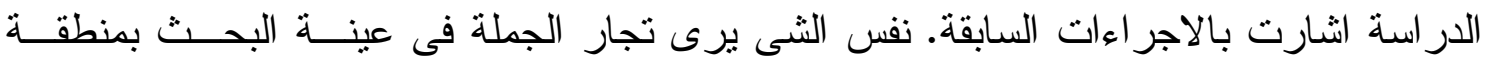

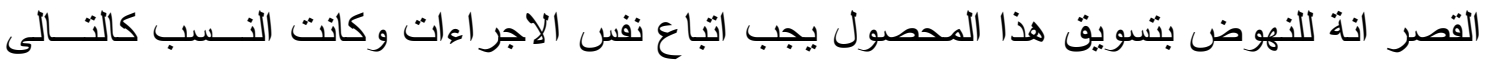

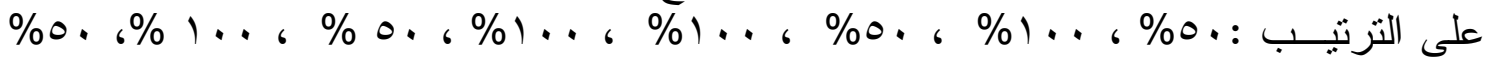

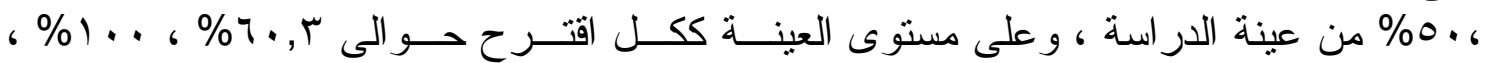

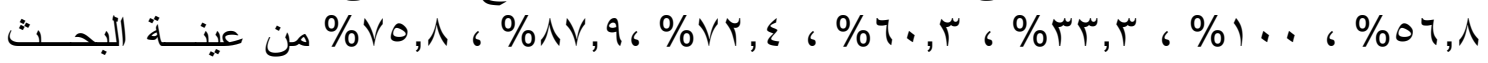

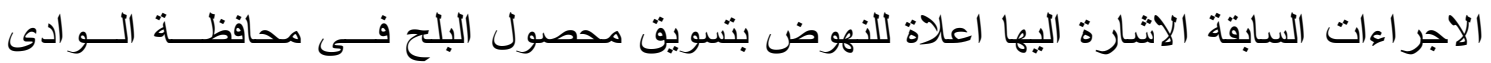


ثانيا : تجار التجزئة: 1-مصدر ووقت ومكان شراء أبراء البلح.

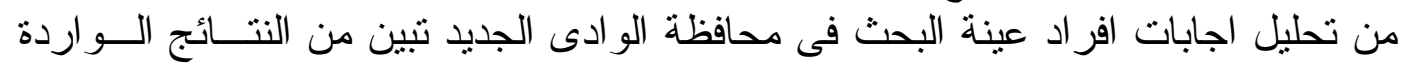

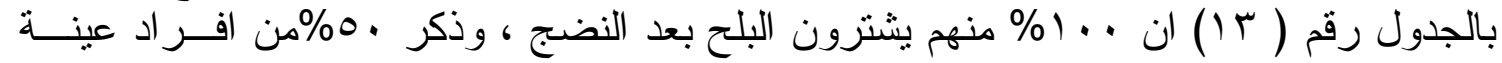

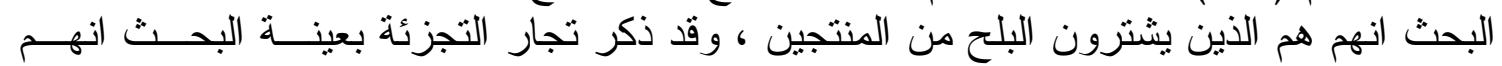
يفضلون الثر اء من المنتجين للاسباب الاتية :

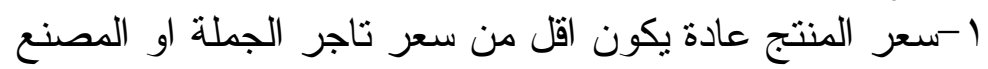

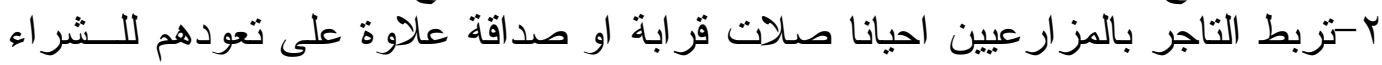

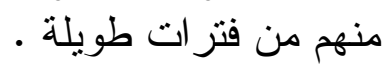

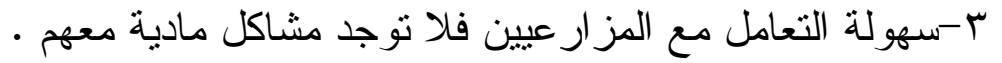

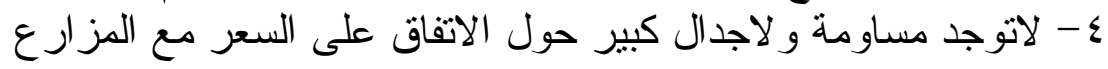

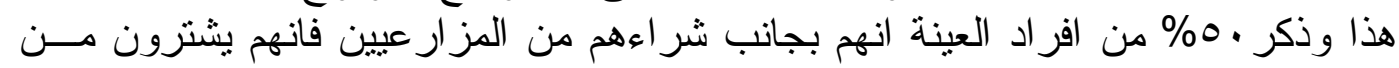

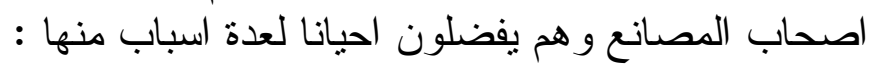

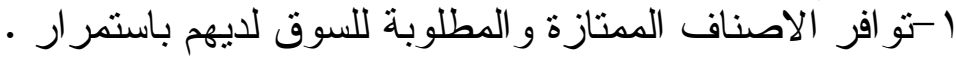

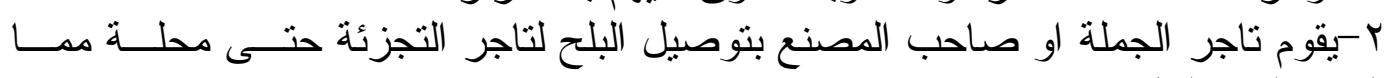

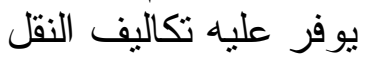

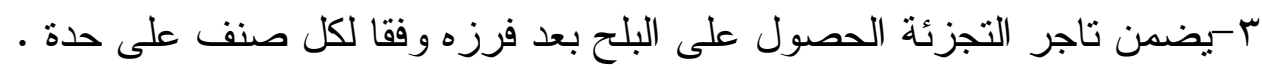

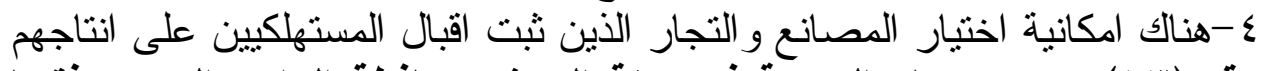

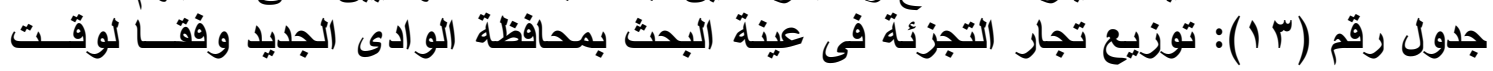

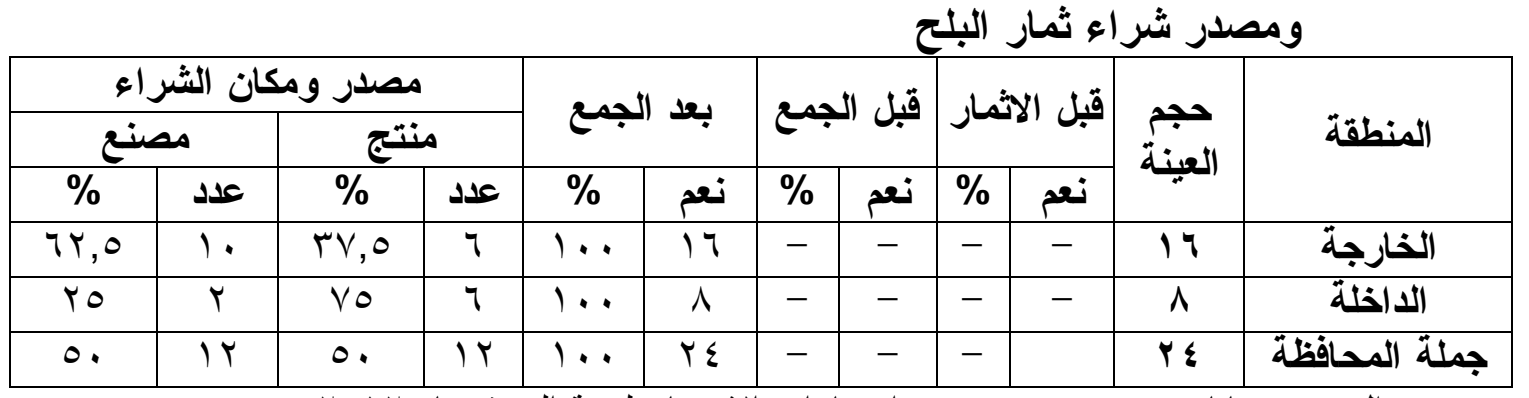

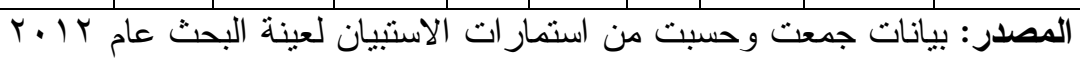

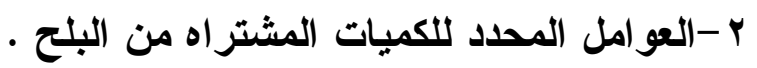

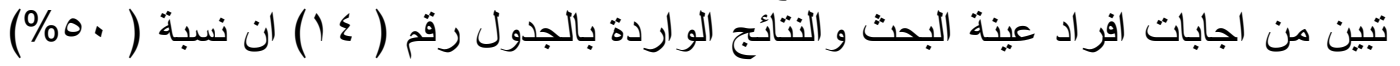

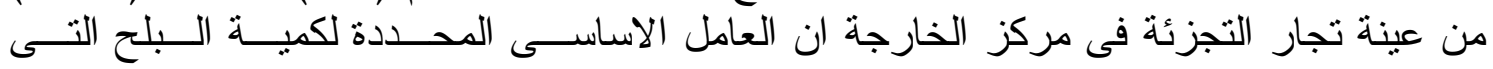

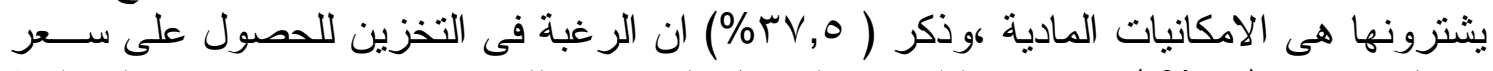

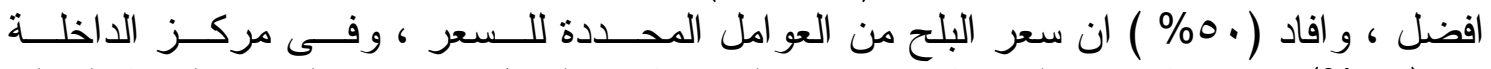

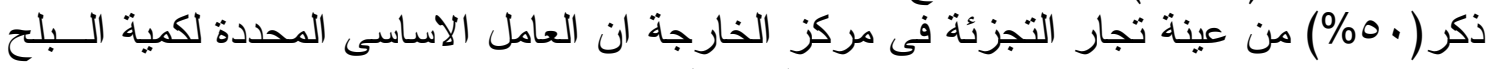

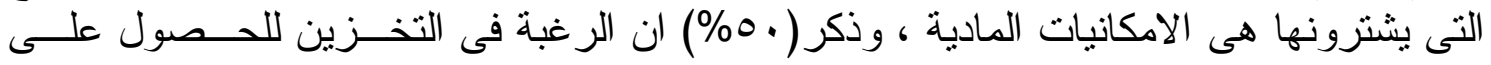

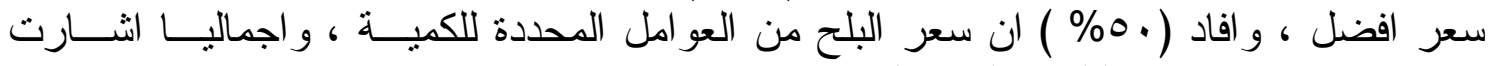

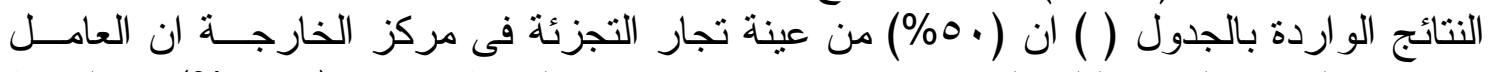

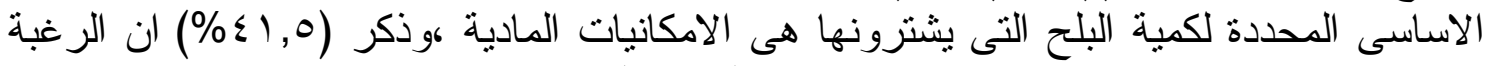

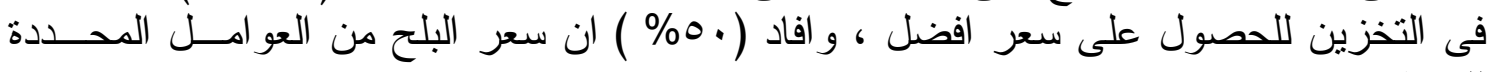
للكمية. 
جدول رقم (؛ 1): توزيع تجار التجزئة في عينة البحث بمحافظة الوادى الجديد وفقا للعوامـل التى تحدد الكميات المشتراة ثمار البلح

\begin{tabular}{|c|c|c|c|c|c|c|c|}
\hline$\%$ & الرغبة فين & $\%$ & الامكاتيات & $\%$ & سعر & حلعن & العو امل \\
\hline$r v, 0$ & 7 & 0. & $\Lambda$ & 0. & $\wedge$ & 17 & الخارجة \\
\hline 0. & $\xi$ & 0. & $\varepsilon$ & 0. & $\varepsilon$ & $\Lambda$ & اللاخلة: \\
\hline 51,77 & 1. & 0. & IT & 0. & IY & T\& & الجملة \\
\hline
\end{tabular}

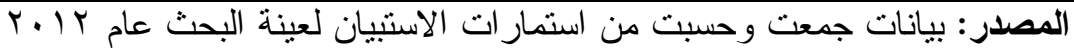

r- مدى اجراء عملية تدريج للثمار ومعاييرة.

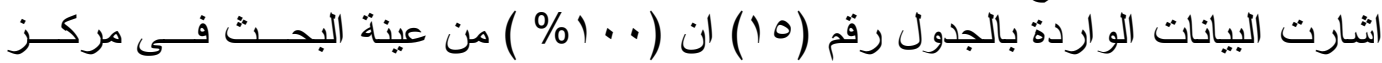

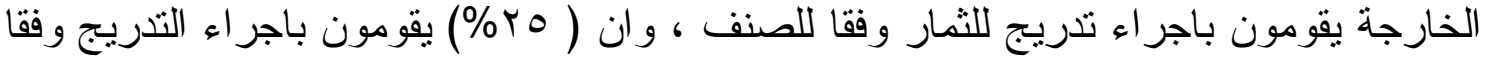

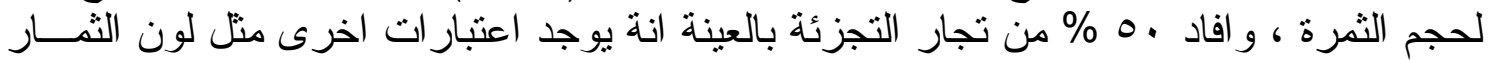

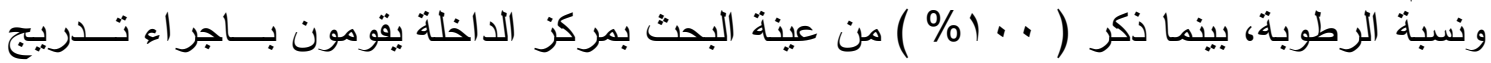

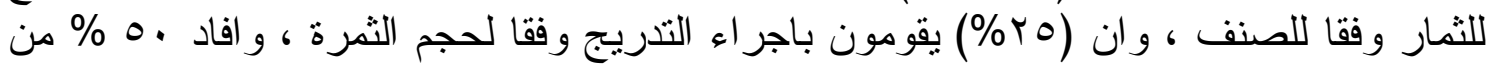

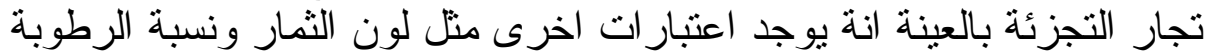

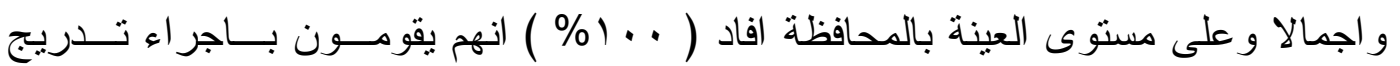

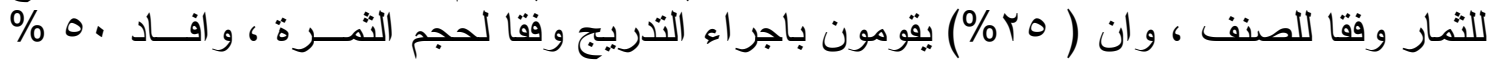

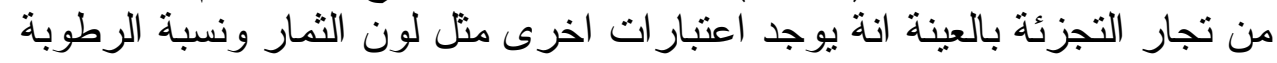

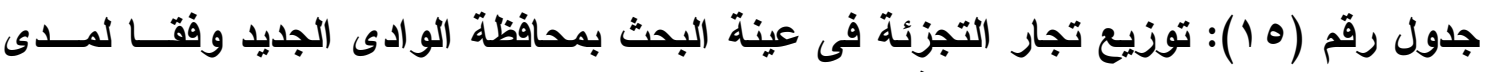

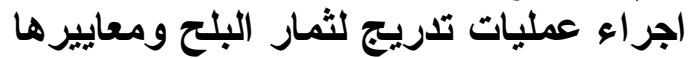

\begin{tabular}{|c|c|c|c|c|c|c|c|c|c|}
\hline \multirow{2}{*}{\multicolumn{2}{|c|}{$y$}} & \multicolumn{6}{|c|}{ نعم } & \multirow{3}{*}{ العينْة } & \multirow{3}{*}{ /المنو امل / /لمقة } \\
\hline & & \multicolumn{2}{|c|}{ اعتبار ات اخرى } & \multicolumn{2}{|c|}{ الحجم } & \multicolumn{2}{|c|}{ الصنف } & & \\
\hline$\%$ & عدد & $\%$ & عدد & $\%$ & عدد & $\%$ & عدد & & \\
\hline- & - & 0 . & $\Lambda$ & ro & $\varepsilon$ & $1 \ldots$ & 17 & 17 & الخارجة \\
\hline- & - & 0 . & $\varepsilon$ & ro & r & $1 \ldots$ & $\Lambda$ & $\Lambda$ & الاخلة \\
\hline- & - & 0 . & Tr & ro & 7 & $1 \ldots$ & $T \varepsilon$ & $r \leqslant$ & جملة \\
\hline
\end{tabular}

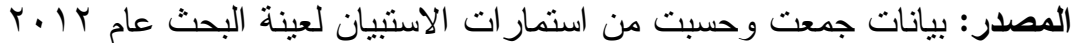

ع - العوامل المحددة لسعر البلح :

تعددت وتتو عت العو امل المحددة لاسعار البلح ففى تبين من البيانات الواردة بالجدول رقم

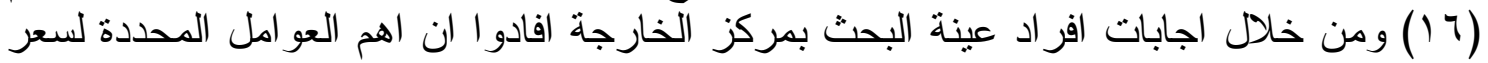

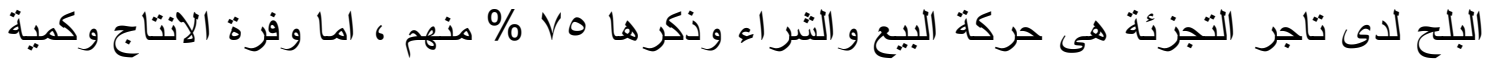

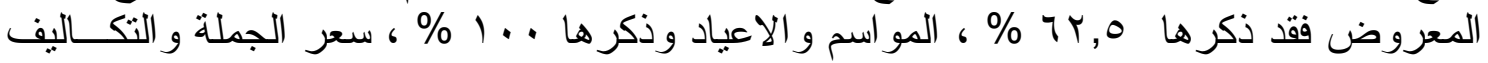

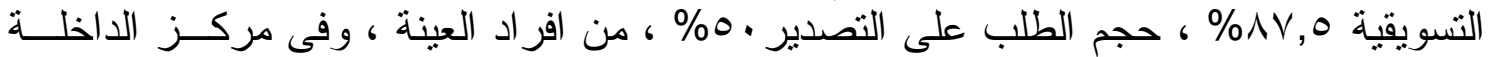

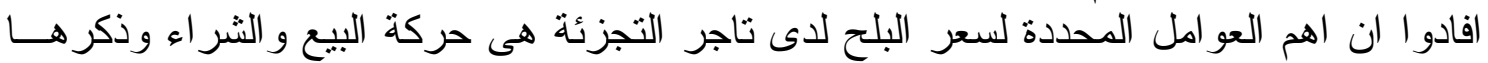

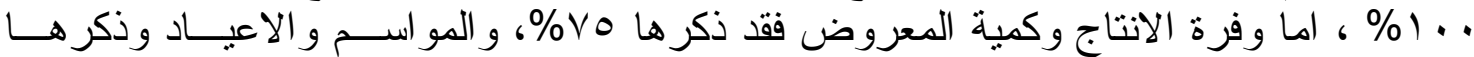

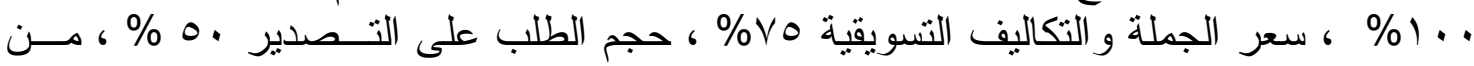

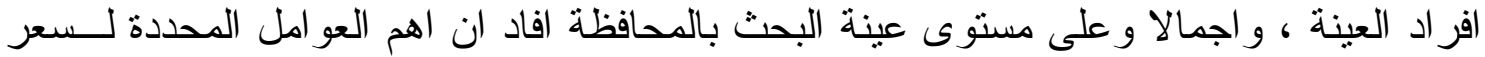

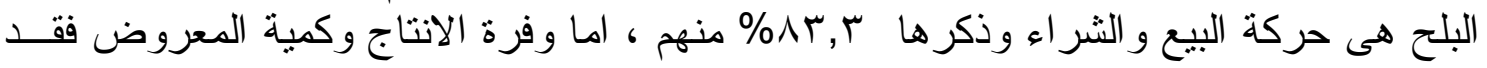

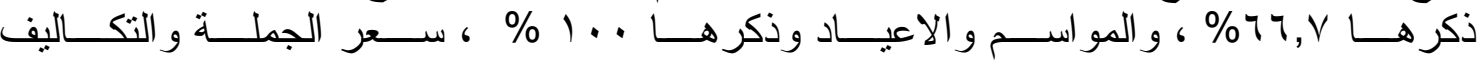

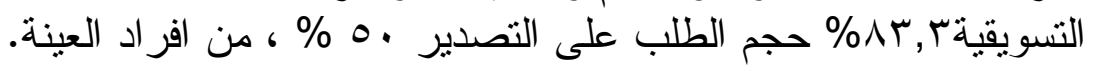


جدول رقم (17) إن توزيع تجار التجزئة فى عينة البحث بالمحافظة وفقا للعوامل المحددة لسعر

\begin{tabular}{|c|c|c|c|c|c|c|c|c|c|c|c|}
\hline & & & & & & & & \multicolumn{4}{|c|}{ مار البـح } \\
\hline \multicolumn{2}{|c|}{0} & \multicolumn{2}{|c|}{$\varepsilon$} & \multicolumn{2}{|c|}{$r$} & \multicolumn{2}{|c|}{$r$} & \multicolumn{2}{|c|}{$T$} & \multirow{2}{*}{ العنفة } & \multirow{2}{*}{ المنطقة } \\
\hline$\%$ & عدد & $\%$ & عدد ( عد & $\%$ & عدد & $\%$ & عدد & $\%$ & عدد & & \\
\hline 0. & $\wedge$ & $\Lambda \vee, 0$ & $1 \leq$ & $1 \ldots$ & 17 & $T Y, 0$ & 1. & Vo & IT & 17 & الخارجة \\
\hline 0. & $\xi$ & Vo & 7 & $1 \ldots$ & $\Lambda$ & Vo & 7 & $1 \ldots$ & $\Lambda$ & $\Lambda$ & الاخلئة \\
\hline 0 . & IT & N & $r$. & $1 \ldots$ & $r \varepsilon$ & $77, V$ & 17 & Nr, & $r$. & $r \leq$ & المحافظة \\
\hline
\end{tabular}

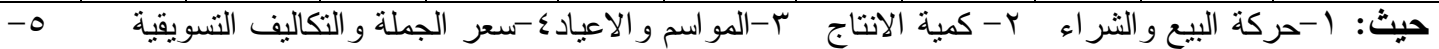
طلبات التصدير

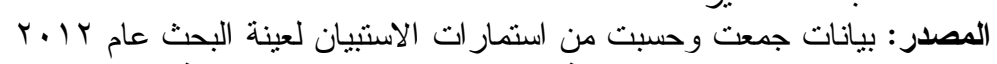
ه-اهم المشكلات التسويقية التى تقابل تجار التجزئة التئة :

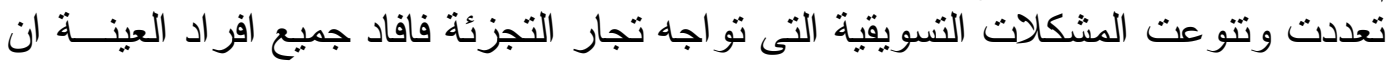

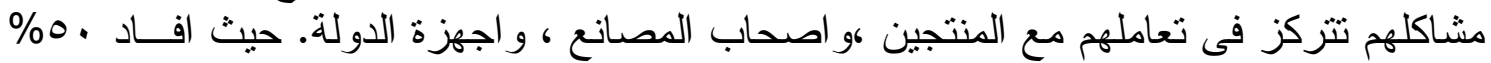

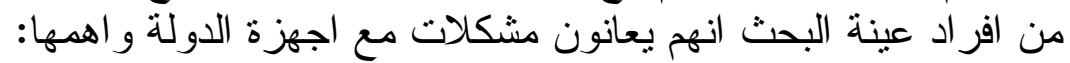

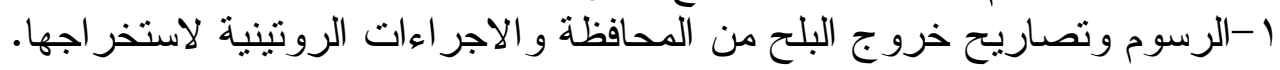

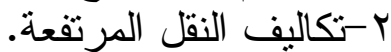

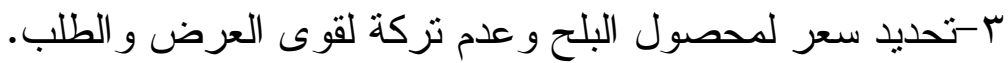

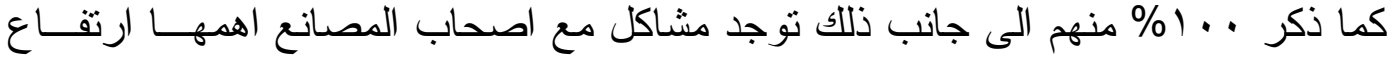

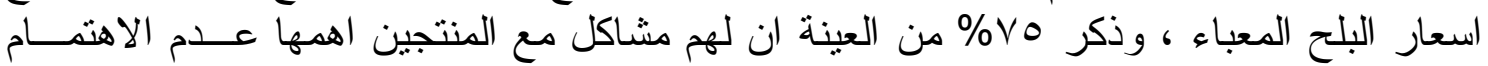

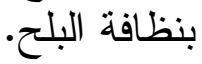

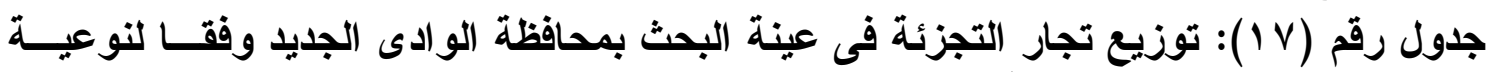
المشاكل التسويقية التى تقابلهم

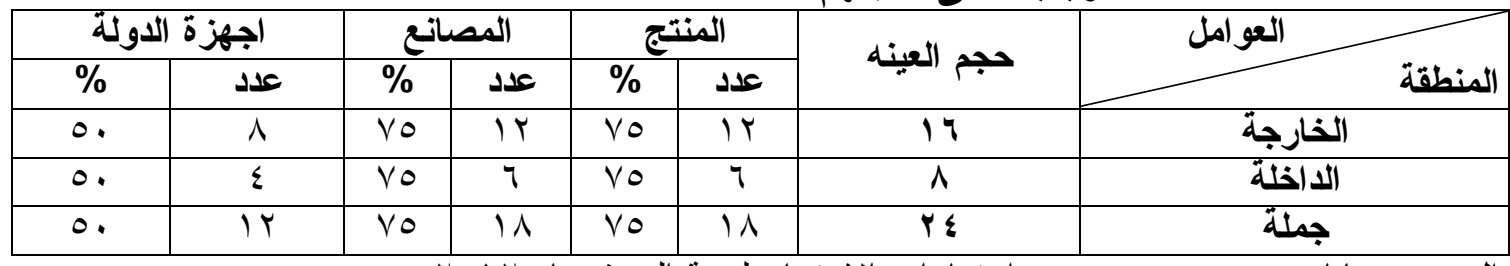

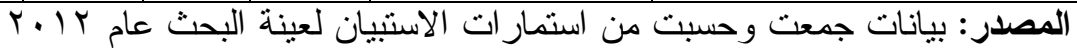

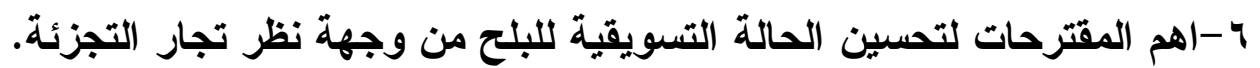

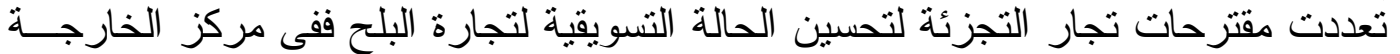

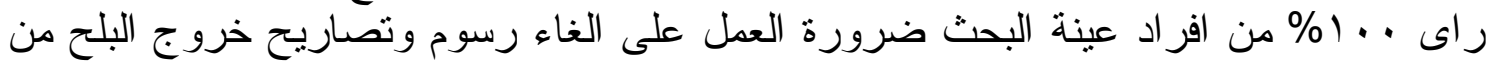

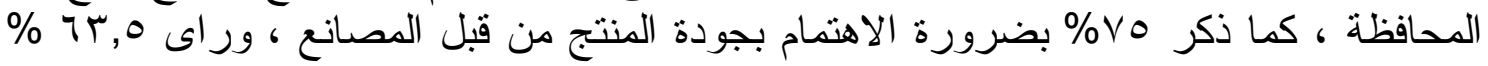

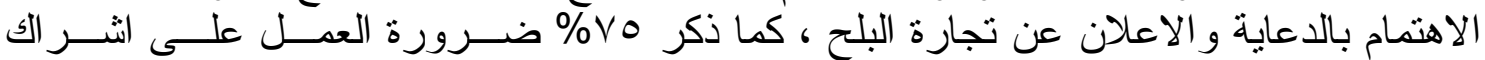

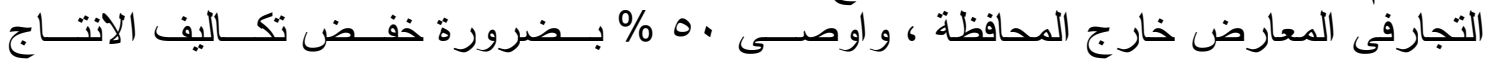

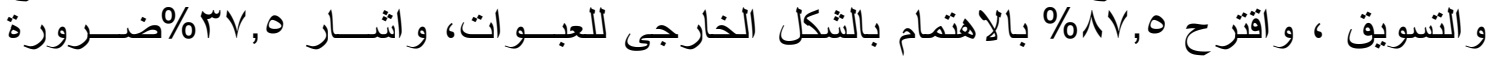

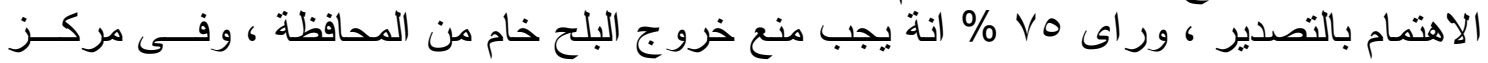

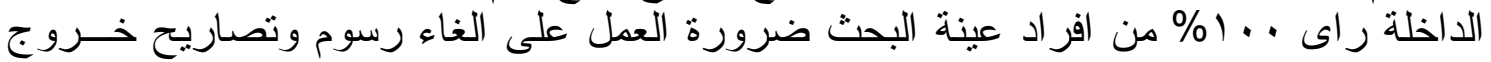

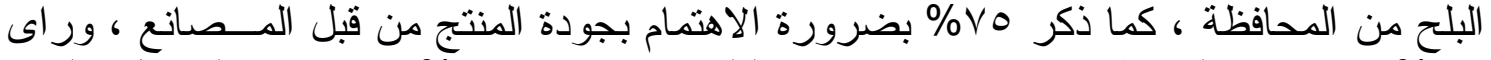

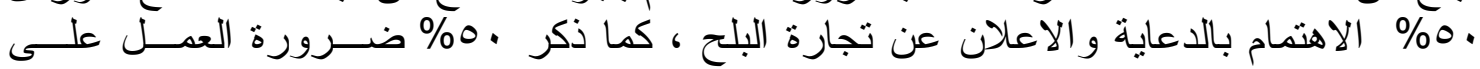

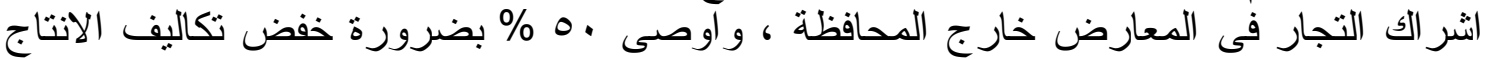

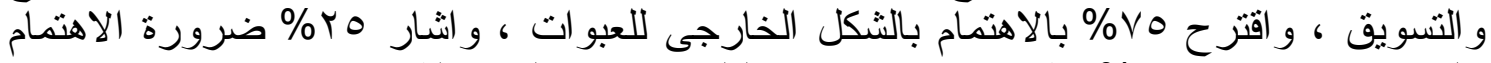

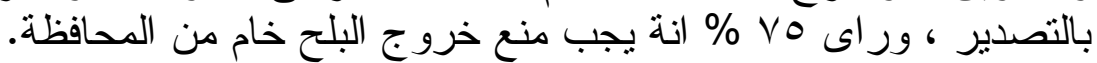

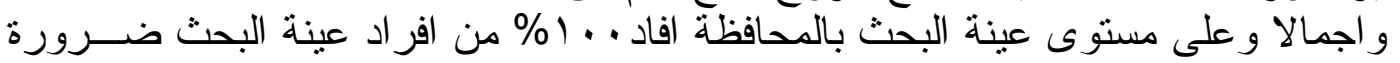

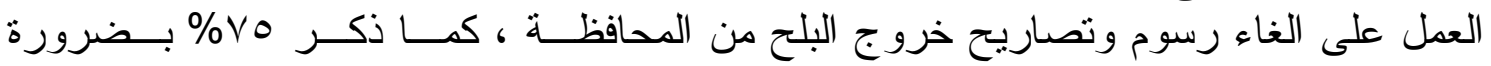

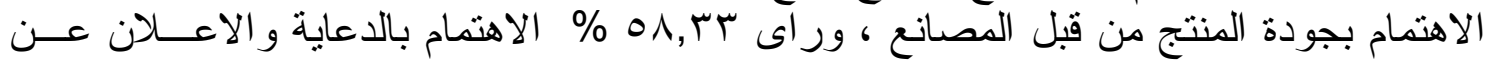




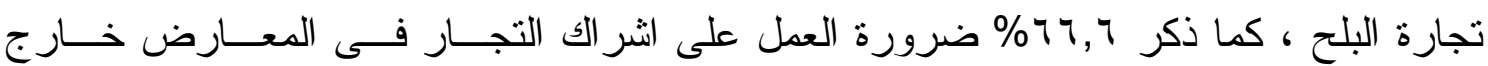

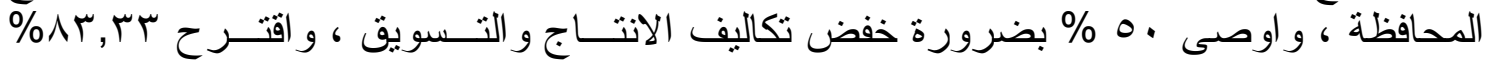

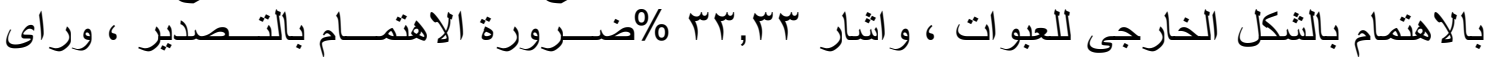
\% vo

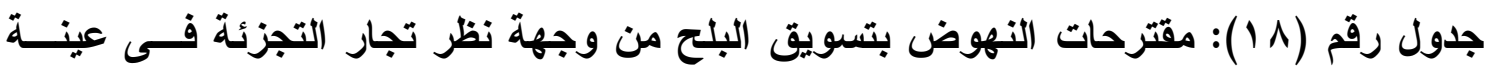
البحث بمحافظة الوادى الجيد الجديد

\begin{tabular}{|c|c|c|c|c|c|c|c|c|c|c|c|c|c|c|c|c|c|}
\hline \multicolumn{2}{|c|}{$\wedge$} & \multicolumn{2}{|c|}{ V } & \multicolumn{2}{|l|}{7} & \multicolumn{2}{|c|}{0} & \multicolumn{2}{|c|}{$\varepsilon$} & \multicolumn{2}{|c|}{$r$} & \multicolumn{2}{|c|}{$r$} & \multicolumn{2}{|c|}{1} & \multirow{2}{*}{ العينه } & \multirow{2}{*}{ المنطقة } \\
\hline$\%$ & عدد & $\%$ & عدد & $\%$ & عدد & $\%$ & عدد & $\%$ & عدد & $\%$ & عدد & $\%$ & عدد & $\%$ & عدد & & \\
\hline vo & IT & $r v, 0$ & 7 & $\Lambda \mathrm{V}, 0$ & $1 \varepsilon$ & 0. & $\wedge$ & vo & Ir & $7 \pi, 0$ & 1. & Vo & ir & $1 \ldots$ & 17 & 17 & الخارجة \\
\hline Vo & 7 & ro & r & vo & 7 & 0. & $\varepsilon$ & 0. & $\varepsilon$ & 0. & $\varepsilon$ & Vo & 7 & $1 \ldots$ & $\Lambda$ & $\Lambda$ & الأاخلة \\
\hline- & - & - & - & - & - & - & - & - & - & - & - & - & - & & - & - & باريس \\
\hline - & - & - & - & - & - & - & & - & - & - & - & - & - & & - & - & القصر \\
\hline vo & 11 & سז, זr, & $\wedge$ & תז, & $r$. & 0. & IT & 77,7 & 17 & ON, & $1 \leqslant$ & vo & 11 & $1 \ldots$ & $r \varepsilon$ & $r \varepsilon$ & المحافظة \\
\hline
\end{tabular}

r- الاهتمام بجودة المنتج من قبل المصانع

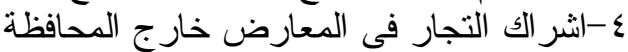

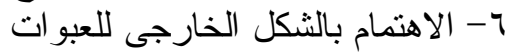

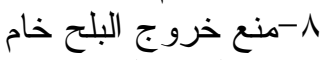
حيث:- - 1-الغاء رسوم خروج البلح من المحافظة ب-الاهنمام بالدعاية و الاعلان 0-خفض تكاليف الانتاج و التسويق

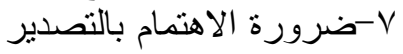

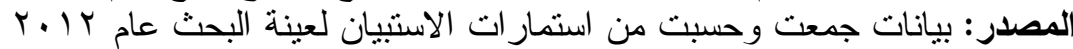
التوصيات:

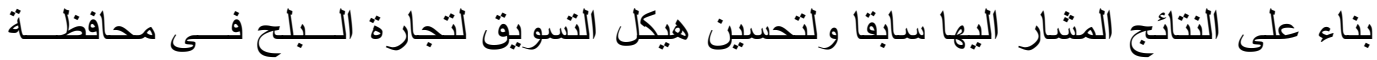

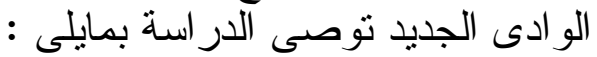

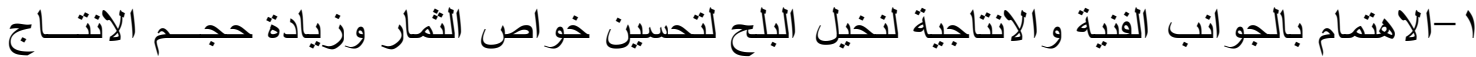

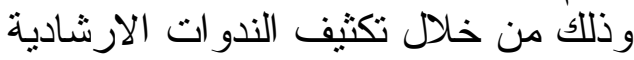

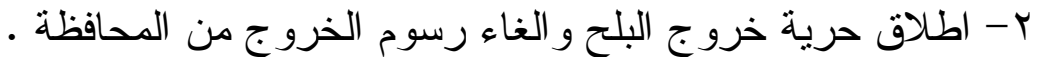

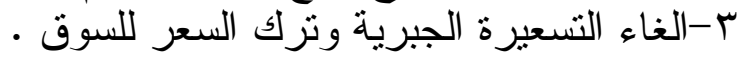

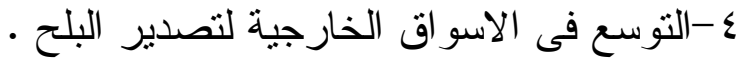

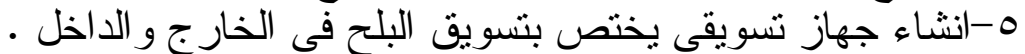

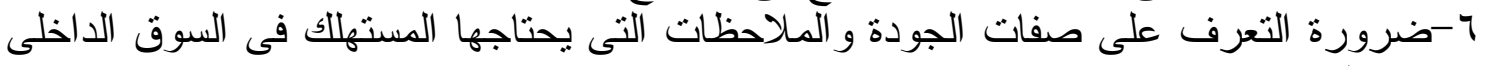

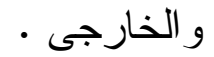
V-ضرورة الاهتمام بعمليات تصنيع وتعبئة وتغليف ثمار البلح ، و العمل على تشجيع الاســثمار

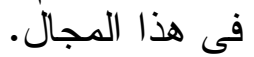

1-الاهتمام بالدعاية و الاعلان للبلح اثر الك التجار فى المعارض خار ج المحافظة و الجمهورية.

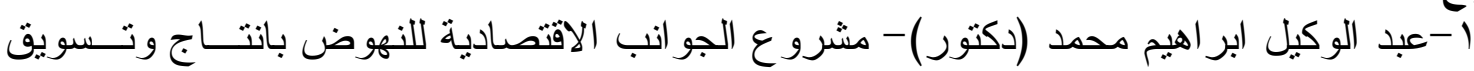

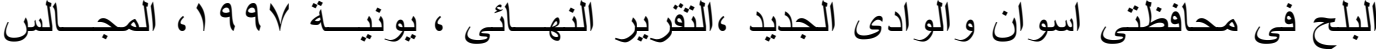

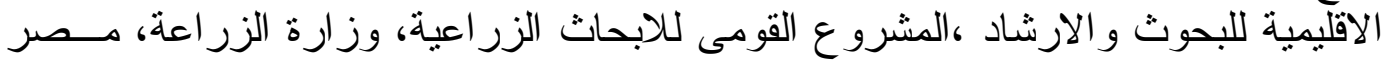
$199 V_{6}$

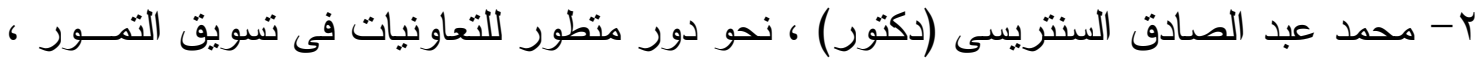

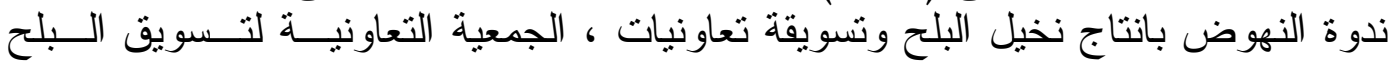

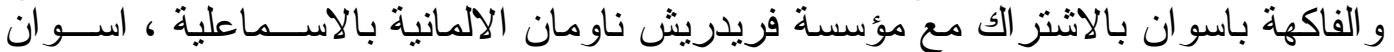

$$
19 \Lambda \mathrm{V} / \mathrm{M} / 10-1 \mathrm{r}_{6}
$$

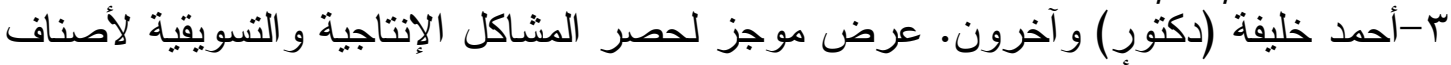

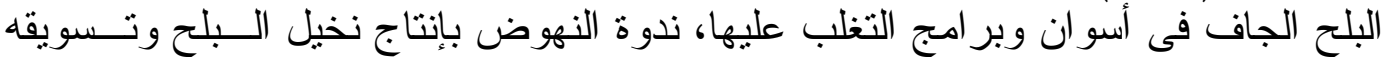

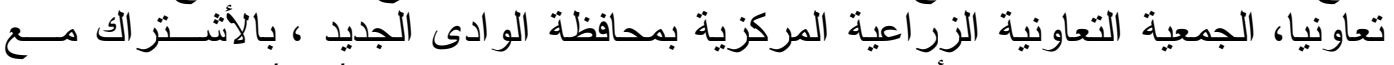

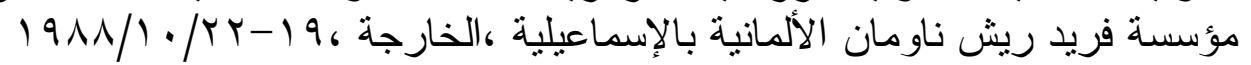




\title{
Some Features of Marketing Date Palm in New Valley Governorate
}

Elhafez, M. M. ${ }^{2}$; A. I. Mohamed ${ }^{1}$; Y. A. Hussein ${ }^{1}$ and A. A. Elbana ${ }^{2}$

${ }^{1}$ Agric. Econ. Dept., Fac. of Agric. , Assiut Univ., Assiut.

${ }^{2}$ Date Palm Research Laborator, Agric. Res. Center

\begin{abstract}
:
Despite the importance of dates crop in the province of New Valley, which is the main crop in the province, but it was noted that this crop is hampered by a set of problems related to aspects of the marketing face wholesalers and retailers. So it was necessary to identify some features of marketing for the dates crop in the New Valley Governorate in addition to the problems that hinder the marketing of dates from the viewpoint of wholesalers and retailers and proposals of the advancement of this important crop, as well as to identify marketing channels (vein marketable) used in marketing dates New Valley Governorate.
\end{abstract}

The study was based on the achievement of its goals on the preliminary data that have been collected through my application questionnaire, one of the wholesalers and other retailers, and the sample included the selection of 58 wholesaler 24 retailer, has been used descriptive method through summarize and describe the data set and the results that could be obtained, which acknowledged the need to identify the quality attributes and observations needed by the consumer in the domestic market and overseas and need to focus on manufacturing operations and Packaging fruits dates, and work to encourage investment in this area and freeing the out dates and the abolition of exit fees from the province.

The study summarized the results of the following:

Interest in the technical aspects and productivity of date palm fruits to improve the properties and increase the volume of production through intensification of seminars guide way Expansion in foreign markets for exporting to mussels Cancel pricing arrest and leave the price of the market. 